Article

\title{
Impact of Banking and Financial Systems on Environmental Sustainability: An Overarching Study of Developing, Emerging, and Developed Economies
}

\author{
Sandra Chukwudumebi Obiora ${ }^{1, *(1)}$, Olusola Bamisile ${ }^{2}$, Evans Opoku-Mensah ${ }^{1}$ (i) \\ and Adasa Nkrumah Kofi Frimpong ${ }^{1}$ (1) \\ 1 School of Management and Economics, University of Electronic Science and Technology of China, \\ No. 2006, Xiyuan Ave, West Hi-Tech Zone, Chengdu 611731, China; evamens2@yahoo.com (E.O.-M.); \\ adasankrumahkofi@gmail.com (A.N.K.F.) \\ 2 School of Mechanical and Electrical Engineering, University of Electronic Science and Technology of China, \\ No. 2006, Xiyuan Ave, West Hi-Tech Zone, Chengdu 611731, China; boomfem@hotmail.com \\ * Correspondence: sandraobiora@gmail.com
}

Received: 3 September 2020; Accepted: 27 September 2020; Published: 30 September 2020

check for updates

\begin{abstract}
In recent years, the developed, emerging, and developing economies have prioritized environmental sustainability attainment. In an attempt to offer some potential policy choices towards the achievement of sustainable development, this paper shifts emphasis from the popularly discussed economic development and carbon emissions nexus. Instead, we examine the impact of the banking and financial system's activities on carbon emissions for a sample of 45 countries. These are comprised of developed, emerging, and developing countries between 1990 and 2017. To fill the gap in the literature, the nexus is examined in seven different phases. This study exposes robust and reliable empirical results with the use of Feasible General Least Squares, random effects with regards to the Durbin-Wu-Hausman test, and Difference General Method of Moments panel data estimation models. Our findings indicate that the increase of domestic credit to the private sector and commercial bank lending consistently contributes towards aggravated carbon emissions in all economic types. Additionally, increased deposit rates in developing economies, increased lending rates in developed economies, and increased deposit rates in emerging economies contribute towards the overall reduction of carbon emissions. The decrease in lending to high GHG emitting members of the private sector by financial institutions in all economies is recommended based on the results of this study.
\end{abstract}

Keywords: environmental sustainability; banking and financial system; developed economies; emerging economies; developing economies

\section{Introduction}

The need to reduce carbon dioxide $\left(\mathrm{CO}_{2}\right)$ emission is one of the world's most pressing issues. Climate change as a result of environmentally unsustainable practices remains the most urgent human development issue of our generation. Problems arising from climate change such as sea-level rise, health risks, agricultural productivity decline, and threats to ecosystems and biodiversity are bound to negatively impact the economic output of all economies in the long run [1]. Among the key drivers of climate change, the rise in Greenhouse gas (GHG) emissions-especially $\mathrm{CO}_{2}$-remains an obstinate obstacle to the achievement of true environmental sustainability. Currently, all economies are faced with the challenge of both satisfying the energy and economic needs of billions of people while simultaneously contributing to the global transition towards a green and low-carbon energy systems. 
This balance is difficult to strike, especially for developing and emerging economies, who aspire to achieve and surpass the levels of economic expansion seen in the developed economies.

In an attempt to offer some potential policy choices towards the achievement of sustainable development, this paper shifts emphasis from the economic development and carbon emissions nexus based on the Environmental Kuznets Curve (EKC) hypotheses, which are already covered extensively in the literature [2-4]. Instead, it explores the banking and financial system and sustainable development nexus. It empirically evaluates the contribution of banking and financial systems as an integral part of economic expansion which is standardly characterized by the ability to provide loans to individuals and the private sector, take deposits, and help with investments.

Existing studies on carbon emission reduction have focused largely on the economic development aspect [5-7]. In other cases, the issue of attaining carbon emissions reduction has been explored in other patterns in energy economics. Kais and Anis [8], along with other researchers [9,10], considered carbon emissions reduction from the perspective of renewable energy production and consumption. Others have examined the carbon emissions and financial development nexus. Farhani and Ozturk [11], in their study of the causal relationship between $\mathrm{CO}_{2}$ emissions and financial development in Tunisia, found that for this developing country, financial development took place at the expense of environmental sustainability. In a similar study done on China, Zhao and Yang [12] found that increments in provincial financial development contributed to carbon emissions reduction. Kim et al. [13] in their study suggested that financial reforms were conducive to better environmental quality. However, these, along with other such studies, tend to focus on specific countries and use varying financial system variables. To the best of our knowledge, none have specifically considered the contribution of the banking system's activities to carbon emissions mitigation efforts in three economic types, as we do in this paper.

The financial sector, especially banks has an important role to play if carbon emission mitigation efforts are to be successful in each economic type. Financial institutions consistently make decisions on whom to lend to and what to invest in. These decisions have the capacity to impact business practices in the long run. High carbon-emitting firms who have easy access to bank loans and private credit whenever needed may continue their standard business practices even at the expense of the environment. These decisions, made by financial institutions on what business to invest in and whom to lend to, among other activities, go a long way towards impacting climate change and the lives of those affected by it. The banking and financial sector, therefore, have a higher level of responsibility to uphold, as this link between their activities and carbon emissions persist. For instance, due to the increased environmental pressures brought on by climate change, the Dutch financial institutions during the Paris Climate Change Summit in 2015 outlined an initiative. The group decided to commit to transparency when assessing the GHG emissions of their investments and loans [14]. In essence, it is not enough for financial institutions to be responsible for their carbon footprint. They also hold responsibility for the outcome of their financial decisions.

This study therefore empirically examines the impact of banking system activities on environmental sustainability. It checks whether a country's banking and financial sector influences carbon dioxide emissions for a sample of 45 countries comprised of developing, emerging, and developed economies between 1990 and 2017. It first considers the banking and financial sector in terms of lending rate, deposit rate, real interest rate, domestic credit to the private sector, and total commercial bank lending. These are analyzed on $\mathrm{CO}_{2}$ emissions in seven different layers, namely: total $\mathrm{CO}_{2}$ emissions, $\mathrm{CO}_{2}$ per capita emissions, emissions by the power industry, by buildings, by the transport sector, by other combustion industries, and by other sectors.

This study fills gaps in the literature in five distinctive ways. (1) This study is the first to consider carbon emissions reduction from a banking system-centered perspective in terms of lending rate (LR), real interest rate (RR) deposit rate (DR), and annual commercial bank lending (CBL). (2) Prior studies $[15,16]$ have also analyzed carbon emissions reduction, but this has often been done either on total carbon emissions or on per capita emissions. However, in this study, an intrinsic look 
at the multifaceted issue of carbon emissions is considered by checking the impact of the banking and financial system on seven layers of carbon emissions. These include: total $\mathrm{CO}_{2}$ emissions, $\mathrm{CO}_{2}$ per capita emissions, emissions by the power industry, by buildings, by the transport sector, by other combustion industries, and by other sectors. (3) While prior studies $[11,17,18]$ have checked specific country blocks or individual countries, we carry out our analysis by considering 15 of each economic type, namely developing, emerging, and developed economies, to gain deeper insights. (4) Our empirical analysis offers valuable insights into the banking and financial system, where carbon emissions mitigation efforts are concerned in a way that has not been considered before. Our final objective is to provide evidence upon which the governments, financial institutions, and policymakers can make better-informed decisions towards the achievement of overall environmental sustainability. (5) To ensure the robustness of our findings, we use three different models, namely feasible general least squares, random effects, and general method of moments panel model estimation approaches, while correcting for endogeneity, autocorrelation, multicollinearity, and heteroskedasticity problems. Furthermore, these models also consider panel data factors and cross-country dependence, which are essential for macro panels that comprise many countries and a longer period.

The rest of this paper is arranged as follows: Section 2 provides a review of all relevant literature as regards economic, financial, and banking sector development on environmental sustainability and the relevant methodologies used to test such nexus. Section 3 discusses the methodological framework used. Section 4 covers the results and discussions, while Section 5 closes the study with a detailed summary of our findings, recommendations, and some concluding statements.

\section{Literature Review}

In this section, we carry out a theoretical review to expound on all relevant literature that has accumulated on the issue of carbon emission reduction. We consider the existing literature on the impact of economic development, financial development, and banking systems on carbon emissions, as well as the gaps in the literature. These studies also offer guidance on the use of panel data estimation approaches for examining the impact of the banking and financial system on carbon emissions mitigation in various industries, sectors, and economic types.

With the emergence of climate change, the pressure to reduce carbon dioxide among other GHG emissions is higher than ever. Many researchers have analyzed various ways via which carbon emissions reduction can be viewed, understood, and achieved in various economies. For instance, Sugiawan et al. [19] carried out a study on the compatibility of carbon dioxide emissions reduction with sustainable well-being. They found that although carbon emissions reduction in developing countries needs to be cautiously evaluated to not decrease well-being, the developed economies can set more ambitious targets for carbon emissions reduction without compromising on well-being. China, among other major emerging economies, has placed emphasis and effort on carbon emissions mitigation. With the initiation of electric vehicles and shared bicycles into the public transportation system, carbon emissions are anticipated to decrease. Zheng et al. [16] carried out a study on electric passenger vehicle sales and carbon emissions reduction potential in China. They found that as much as $70 \%$ of the total gasoline replacement and approximately $80 \%$ of the total carbon emissions reduction were contributed by battery electric vehicles (BEVs). Cao and Shen [20] in their study on shared bikes found that these play comprehensive positive roles for both the environment and the economy. Du et al. [21] considered the contribution of green technology innovations on carbon emissions reduction using patent data. They found that urbanization level, industrial structure, energy consumption, and trade openness significantly affected carbon emissions. They suggest that the cost of green technology in developing economies, however, inhibits efforts towards attaining carbon emissions reduction through green technology.

Other studies have considered carbon dioxide emissions and economic development nexus in various economies and economic types. For this relationship, importance is often placed on the EKC hypothesis coined by Simon Kuznets in the 1950s and 1960s. Kuznets postulated an inverted 
U-shaped curve between per capita income and various pollutants. While some studies validate the EKC, others reject this concept. For instance, while Sarkodie and Strezov [22] in their study of three prominent developed economies reported findings that validate the EKC hypothesis using a linear model, Chen et al. [23] in their study considered the model inadequate due to the bound rationality of humans. Yet, in all cases, the fact that economic development impacts carbon emissions has never been denied.

In various economic types, the subject of simultaneously achieving environmental sustainability and economic development is constantly being broached. In developed economies, especially, the interdependence of environmental degradation, energy consumption, and economic growth has become a public priority. Results are already being seen from the GHG emissions mitigation and green growth efforts [24]. Additionally, the trend in developed economies is an increase in environmental awareness levels and higher consciousness of climate change. In emerging economies, attaining this difficult balance of economic growth and environmental sustainability has proven sensitive. At various governmental levels, this issue is taking precedence as enterprises are being pushed to reduce pollution especially carbon emissions and more stringent environmental regulations are being put in place [17]. In the developing economies, the 'grow first, clean up later' pattern of economic development remains in place. These countries often face great challenges in implementing green growth strategies and have struggles with other pressing issues such as poverty, and energy privation to deal with [25].

The financial development and carbon emissions nexus is another area some researchers have examined in part. Jiang and Ma [26] in their study on this nexus found that for developing economies, financial development has the potential to significantly increase carbon emissions compared to developed and emerging economies. Wang et al. [27] in their study on the nexus of carbon emissions, financial development, and renewable energy consumption found a positive relationship between financial development and carbon emissions.

However, few studies have considered the contribution of the banking system, especially on carbon emissions in different economic types. One study that attempts this is Samour et al. [18], who in their study on Turkey checked the impact the banking sector has on carbon emissions. They found that an increase in the real interest rate positively impacted carbon emissions reduction. Yet, besides overall examination of the financial sector development's impact on carbon emissions, it is evident that very little research has been done on the impact of key banking system agents on carbon emissions like we do in this study. In this study, we check the impact of key aspects of the banking and financial system namely lending rate, deposit rate, real interest rate, domestic credit to the private sector, and commercial bank lending on carbon emissions. We check these on seven layers of carbon emissions, namely total carbon emissions, per capita emissions, carbon emissions by transport, buildings, power industry, other combustion industries, and other sectors.

Besides the clear literature gap, a second motivation of the present study is to use up-to-date econometric techniques in our empirical analysis. Our methodology to test the nexus between the banking system and environmental sustainability is informed by several studies [28-32] that used various econometric models including Feasible General Least Squares (FGLS), Ordinary Least Squares, fixed effects, and random effects, and difference or system General Method of Moments models separately in testing various nexus relationships. In this study, we therefore use not one, but three main models, namely FGLS, Random Effects, and GMM, to ensure the robustness of our findings.

\section{Methodology}

\subsection{Data and Sample Selection Procedure}

Based on Hansen's [33] recommendations for panel data and data availability limitations, we collected annual data from 45 countries comprised of developing, emerging, and developed economies to make an unbalanced panel data set (see Table A1). The explanatory variables data sets were obtained from the World Bank database. These banking and financial data sets were made 
available by the International Monetary Fund. The environmental sustainability data sets were obtained from the Publication Office of the European Union database. These were also accessed via the World Bank database. The countries for each economic type have been selected based on several characteristics that define them. First, the developing countries used are characterized by low real income per capita levels compared with other countries, higher unemployment rates, higher population growth rates, higher dependence on the primary sector, as well as lower standards of living. Next, the emerging economies selected are characterized by their ability to have GDP annual growth rates that are comparable to those of the developed countries. Additionally, they often bear several characteristics found both in developing and developed economies. Currently, as much as $80 \%$ of the world's economy is driven by such countries, with some of the largest and most influential being China, India, and Russia [34]. Lastly, the developed economies selected make up the majority of the OECD countries. These are often characterized by their higher standards of living, lower unemployment rates, lower population growth rates, higher per capita income levels, as well as higher economic contributions from the service and industrial sectors.

\subsection{Variables and Descriptive Statistics}

Table 1 reports the variables, abbreviations, definitions, and sources for all the dependent and explanatory variables used in the present study.

Table 1. Definition of Variables.

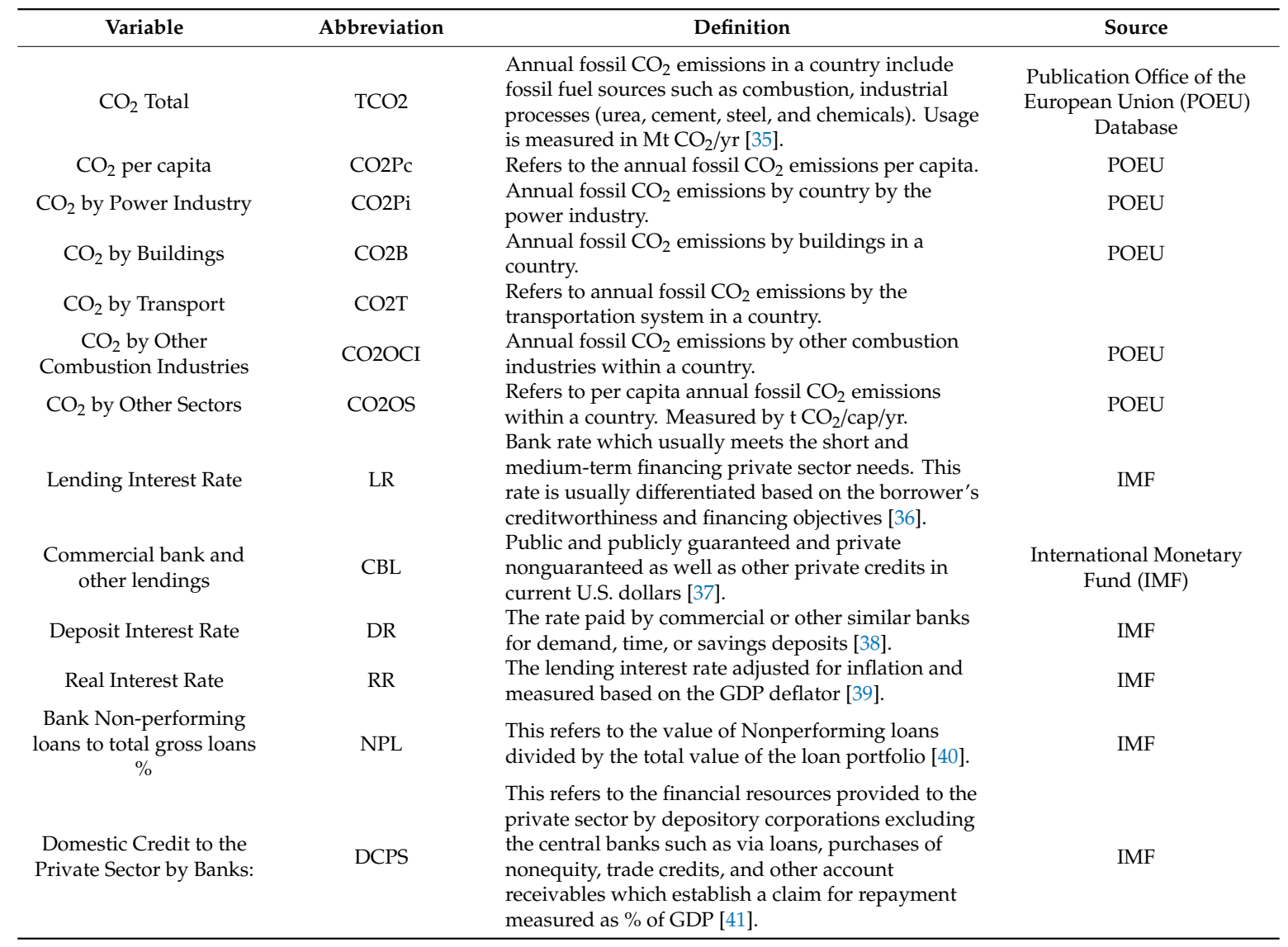

Figure 1, below, provides the conceptual framework of the relationship between the variables. 


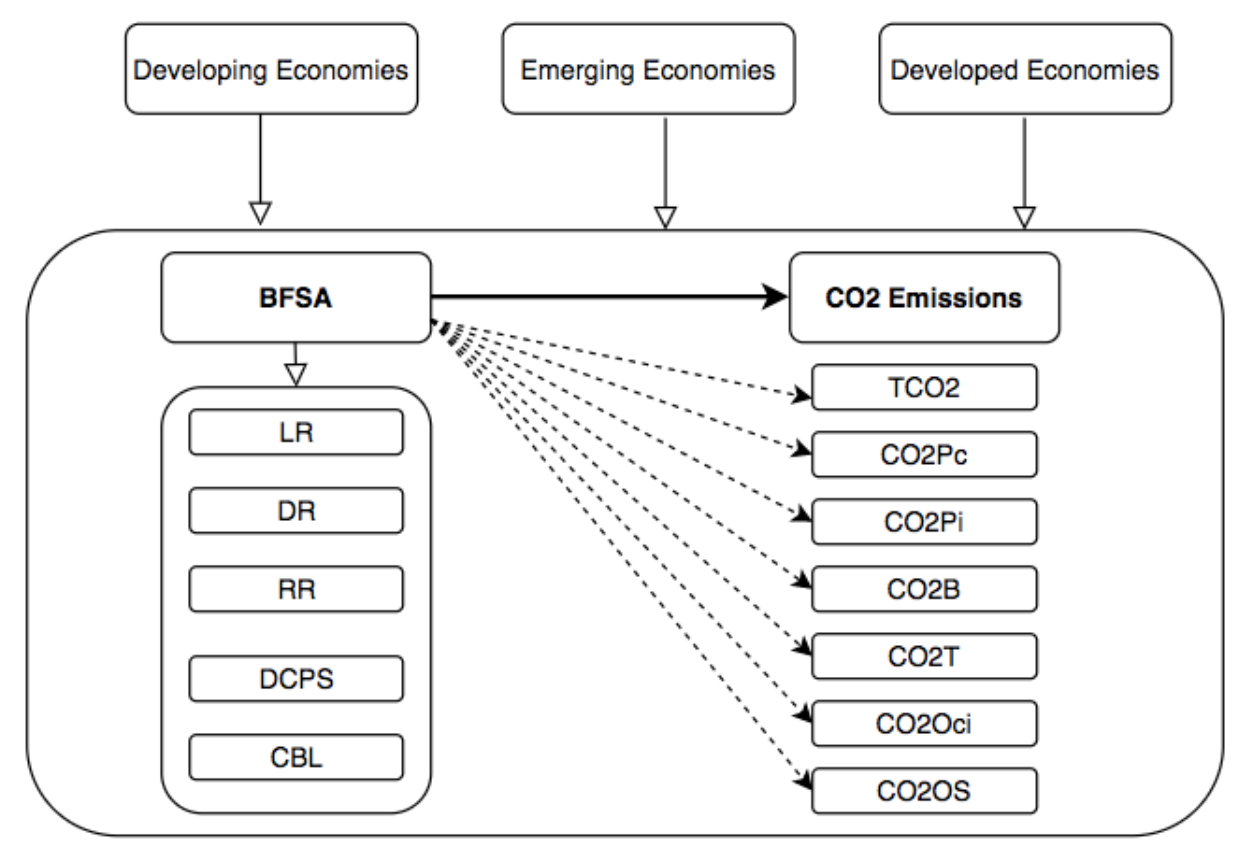

Figure 1. Conceptual framework. Source: Author's illustrations.

BSFA are the explanatory variables that refer to banking and financial sector activities. These include lending rate (LR), deposit rate (DR), real interest rate (RR), domestic credit to the private sector (DCPS), and commercial bank lending (CBL). The dependent variable is carbon emissions, separated into seven categories. Total carbon emissions (TCO2), per capita carbon emissions (CO2Pc), emissions by the power industry $(\mathrm{CO} 2 \mathrm{Pi})$, by buildings $(\mathrm{CO} 2 \mathrm{~B})$, by transportation sector $(\mathrm{CO} 2 \mathrm{~T})$, by other combustion industries (CO2OCI), and by other sectors (CO2OS).

\subsection{Panel Estimator}

In analyzing the BFSA and carbon emissions nexus, three methodologies used in the existing literature are considered. Recent studies [31,42,43] have used the Feasible General Least Squares (FGLS), fixed and random effects panel model estimation approaches to check various nexus dynamics similar to what we are testing in this study. The Generalized Method of Moments (GMM) has also been popularly used in recent key studies $[28,32,44]$ as a robustness measure for checking financial or banking sector development with economic growth or on other explanatory variables such as carbon emissions. In this study, we use panel data from 45 countries, consisting of 15 developing, emerging, and developed economies, between 1990 and 2017. We use the FGLS panel model estimator, random-effects model, and Difference GMM to estimate BSA and carbon emissions nexus in seven layers.

According to Aitken [45], the GLS estimator is unbiased, consistent, efficient, and asymptotically normal compared with a simple OLS estimator model. Miller [46] also presents the FGLS estimator model as a preferable approach because it corrects for heteroskedasticity and autocorrelation issues. The FGLS and GMM estimators also control for slope endogeneity and cross-sectional dependence. With the variance-covariance model, we further make sure that our analysis is free of all multicollinearity problems. The correlation coefficient matrices for each economic type show that the explanatory variables used do not affect one another and that these are homoscedastic in nature. For the estimation of the results for each economic type, the FGLS estimation approach has been used over the GMM primarily because the number of years $\mathrm{N}=27$ exceeds the number of countries $\mathrm{n}=15$. Thus, the GMM estimation approach is used mainly as a robustness check for all 45 countries afterwards. We use the standard FGLS estimator model $\hat{\beta}_{F G L S}$, which is defined as:

$$
\hat{\beta}_{F G L S}=\left(X^{\prime} \hat{W}^{-1} X\right)^{-1} X^{\prime} \hat{W}^{-1} Y
$$


where $\hat{W}$ is a diagonal matrix with the entries $\hat{v}_{l l}=\hat{u}_{l}{ }^{2}$.

To investigate the relationship between BSA and carbon emissions for each economic type, several econometric techniques were used for the estimation, all of which are variants of the following baseline model:

$$
C O 2_{i t}=\alpha_{i t}+\beta_{1} L R+\beta_{2} D R+\beta_{3} R R+\beta_{4} D C P S+\beta_{5} C B L+\varepsilon_{i t}
$$

where $i=1,2, \ldots, N$ for each region in the panel and $t=1,2, \ldots, T$ refers to the period. $\beta$ is the population Y-intercept. Lending rate (LR), deposit rate (DR), real interest rate (RR), domestic credit to the private sector (DCPS), and commercial bank lending (CBL) are the explanatory variables for BFSA, while $\varepsilon_{i t}$ is the error term.

We make use of the (Durbin-Wu-) Hausman test for the decision between using random or fixed effects. Following the Hausman test results, we therefore use the random-effects model for the economies. We use the Wooldridge (2010) unrelatedness assumption (RE1) approach [47] with the following auxiliary regression equation:

$$
y_{i t}=\alpha+x_{\imath t}^{\prime} \beta+z_{\imath}^{\prime} \gamma+\bar{x}_{\imath}^{\prime} \lambda+\beta+\delta_{t}+u_{i t}
$$

where $i=1, \ldots, t=1, \ldots, T$ and $\bar{x}_{i}=1 / T \sum_{t} x_{i t}$ refers to the time averages of all time-varying regressors. This includes time fixed $\delta_{t}$ if included in the RE and FE estimation.

As a robustness measure, we use the difference GMM estimation approach to check the effect of BSA on all seven layers of carbon emissions for all economic types with the standard estimation formula:

$$
\hat{\theta}=\arg \min _{\theta \epsilon \Theta}\left(\frac{1}{T} \sum_{t=1}^{T} g\left(Y_{t}, \theta\right)\right)^{T} \hat{W}\left(\frac{1}{T} \sum_{t=1}^{T} g\left(Y_{t}, \theta\right)\right)
$$

where $T$ is the number of observations, $Y$ is the generic observation. $W$ is the positive-definite weighting matrix and $m^{T}$ denotes transposition. Additionally, the Sargan test for over-identification issues and the Arrellano-Bond autocorrelation tests are carefully considered.

For this research, we use Stata as our tool for running each of the above-described models, and $\mathrm{R}$ for plotting the bivariate scatter plots.

Table 2 reports the descriptive statistics for all economic types. The mean and standard deviation for each economic type-namely developing economies (DPE), emerging Economies (EE), Developed economies (DE), and all economies (AE) — are given.

Table 2. Descriptive statistics.

\begin{tabular}{cccccccccc}
\hline \multicolumn{2}{c}{ DPE } & \multicolumn{2}{c}{ EE } & \multicolumn{2}{c}{ DE } & \multicolumn{2}{c}{ AE } \\
\hline Variables & Mean & SD & Mean & SD & Mean & SD & Mean & SD & Obs. \\
\hline TCO2 & 12.38757 & 31.8286 & 767.8562 & 1736.187 & 638.6564 & 1352.469 & 472.7033 & 1311.868 & 1258 \\
CO2PI & 3.217071 & 8.862628 & 305.3562 & 713.5789 & 360.9762 & 745.8039 & 223.1832 & 615.897 & 1260 \\
CO2B & 1.442429 & 3.606218 & 70.18393 & 134.6089 & 76.81683 & 148.8289 & 49.48106 & 120.6993 & 1260 \\
CO2T & 3.43981 & 7.347826 & 84.45438 & 125.3902 & 168.4731 & 404.0361 & 85.45577 & 253.2244 & 1260 \\
CO2OCI & 2.790738 & 8.173936 & 198.3445 & 519.5484 & $3.23 \times 10^{11}$ & $6.07 \times 10^{11}$ & $1.08 \times 10^{11}$ & $3.82 \times 10^{11}$ & 1260 \\
CO2OS & 1.56531 & 4.115342 & 109.5286 & 270.9522 & 39.89371 & 68.46376 & 50.32921 & 167.3234 & 1260 \\
CO2PC & 0.3316905 & 0.4107537 & 5.203071 & 6.63212 & 11.49055 & 5.292866 & 5.675103 & 6.700684 & 1260 \\
LR & 30.83881 & 83.55774 & 16.37703 & 12.70251 & 5.864127 & 3.31081 & 17.84362 & 50.11409 & 857 \\
DR & 9.140582 & 5.183945 & 79.25485 & 632.2717 & 2.957668 & 2.935769 & 35.24581 & 400.036 & 817 \\
RR & 19.72611 & 84.25099 & 6.488486 & 12.37089 & 4.009763 & 2.937947 & 10.1189 & 49.7649 & 856 \\
DCPS & 13.53776 & 9.334346 & 55.06202 & 39.30423 & 119.413 & 44.46333 & 61.25901 & 55.14937 & 1187 \\
CBL & $7.28 \times 10^{7}$ & $3.44 \times 10^{8}$ & $3.71 \times 10^{9}$ & $1.16 \times 10^{10}$ & & & $1.76 \times 10^{9}$ & $8.08 \times 10^{9}$ & 784 \\
\hline
\end{tabular}

Table 3 provides the correlation coefficient matrix for all economies. 
Table 3. Correlation coefficient matrix for all economies.

\begin{tabular}{cccccc}
\hline & LR & DR & RR & DCPS & CBL \\
\hline LR & 1.0000 & & & & \\
DR & 0.6598 & 1.0000 & & & \\
RR & 0.6949 & 0.2511 & 1.0000 & & \\
DCPS & -0.2294 & -0.2243 & -0.0599 & 1.0000 & \\
CBL & 0.0351 & -0.1223 & 0.0372 & 0.1923 & 1.0000 \\
\hline
\end{tabular}

Overall, there are no strong negative or positive correlations between the explanatory variables. Although not especially strong, there is a slight indication of a moderate positive correlation between the lending rate and deposit rate, as well as between lending rate and real interest rate. Nevertheless, this positive correlation is expected as the other bank rates especially the lending rate are decided based on the real interest rate which is set by the central banks.

\section{Empirical Results and Discussions}

In this section, the FGLS, random effects, and GMM estimation results for the banking system and carbon emissions nexus are provided and elucidated. We discuss the findings for the impact of the banking and financial system on carbon emissions between 1990 and 2017. We analyze by first checking this nexus on total annual carbon emissions, then on total per capita emissions, emissions by the power industry, by buildings, by the transportation sector, by other combustion industries, then by other sectors. Following the concept of the environmental Kuznets curve hypothesis, it is expected that an increase in the banking and financial system (BFSA) variables will lead to an overall increase in carbon emissions over time. The preferred outcome would be that increase or decrease in BFSA variables should, over these 27 years, contribute to a decrease rather than an increase in carbon emissions in all seven layers. As a sample to test the EKC concept, Figure 2 provides a visual representation using bivariate scatterplots to check the effect of domestic credit to the private sector as a financial system variable on carbon emissions for all economies.
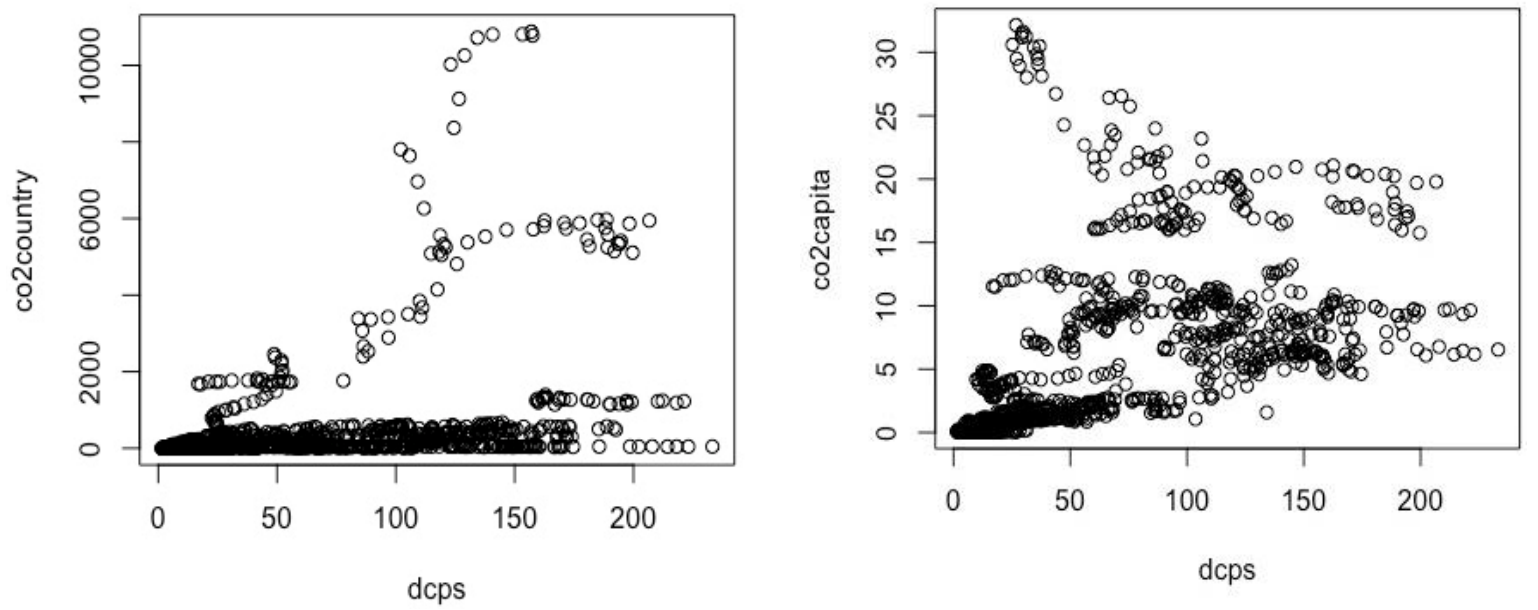

Figure 2. Cont. 

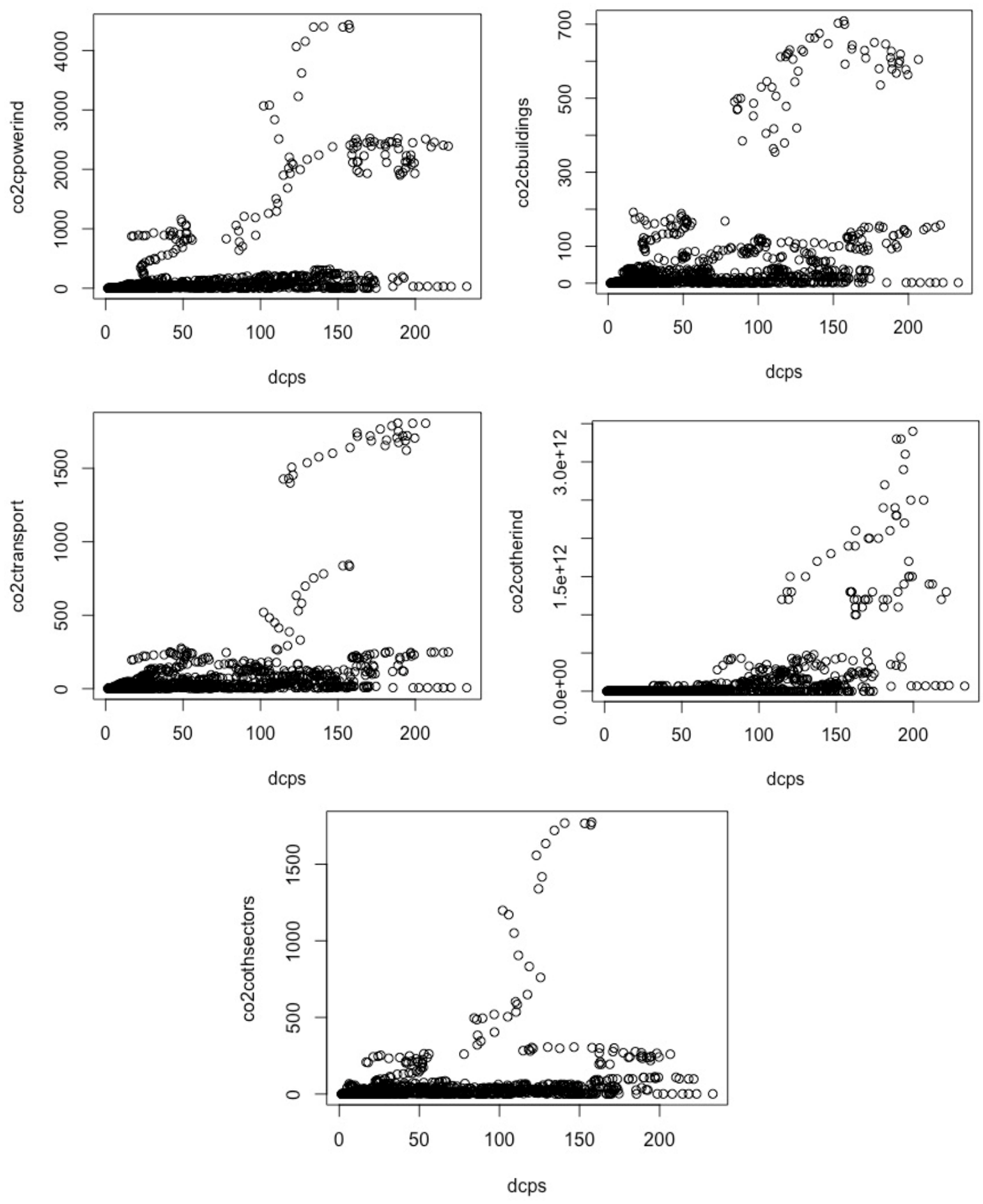

Figure 2. Effect of domestic credit to the private sector on seven layers of $\mathrm{CO}_{2}$ emissions. Source: Author's illustrations based on WBS and IMF Database.

In all cases, we observe a significant positive correlation between DCPS and carbon emissions. This indicates that based on the EKC hypothesis, BFSA increase is still at the stage of leading to increased environmental degradation via carbon emissions increase. Between 1990 and 2017, there is no evidence of an inverted U-shaped curve.

To empirically test the BFSA and carbon nexus in multivariate regression, FGLS and random effects models are used. The results are presented in Tables 4-12. 
The estimation results for the effect of the banking and financial system activities (BFSA) on total annual carbon emissions for all economic types are found in Table 4.

Table 4. Effect of banking and financial system activities on total $\mathrm{CO}_{2}$ emissions.

\begin{tabular}{|c|c|c|c|c|c|c|c|c|}
\hline Variables & (1) & (2) & (3) & (4) & (5) & (6) & (7) & (8) \\
\hline & DPE & & $\mathrm{EE}$ & & DE & & $\mathrm{AE}$ & \\
\hline & FGLS & RE & FGLS & RE & FGLS & RE & FGLS & RE \\
\hline LR & $\begin{array}{c}0.474 \\
(0.311)\end{array}$ & $\begin{array}{l}-0.0555 \\
(0.0623)\end{array}$ & $\begin{array}{c}18.65 \\
(24.51)\end{array}$ & $\begin{array}{l}99.19^{* * *} \\
(23.54)\end{array}$ & $\begin{array}{c}-123.1^{* * *} \\
(15.78)\end{array}$ & $\begin{array}{l}-4.410 \\
(3.367)\end{array}$ & $\begin{array}{c}7.967 \\
(9.437)\end{array}$ & $\begin{array}{c}20.25^{* * *} \\
(7.777)\end{array}$ \\
\hline DR & $\begin{array}{c}-1.277^{* *} \\
(0.543)\end{array}$ & $\begin{array}{l}0.0195 \\
(0.100)\end{array}$ & $\begin{array}{c}-91.15^{* * *} \\
(34.10)\end{array}$ & $\begin{array}{c}-107.9^{* * *} \\
(27.57)\end{array}$ & $\begin{array}{c}128.0 * * * \\
(15.91)\end{array}$ & $\begin{array}{c}0.226 \\
(3.677)\end{array}$ & $\begin{array}{c}-46.35^{* * *} \\
(15.73)\end{array}$ & $\begin{array}{c}-22.42 * * \\
(10.60)\end{array}$ \\
\hline RR & $\begin{array}{c}-0.417^{* *} \\
(0.203)\end{array}$ & $\begin{array}{l}0.0697^{* *} \\
(0.0329)\end{array}$ & $\begin{array}{l}-22.16 \\
(17.96)\end{array}$ & $\begin{array}{c}-19.26^{*} \\
(10.19)\end{array}$ & $\begin{array}{c}9.125 \\
(9.519)\end{array}$ & $\begin{array}{c}-3.601^{* * *} \\
(1.213)\end{array}$ & $\begin{array}{l}-9.849 \\
(6.701)\end{array}$ & $\begin{array}{l}-4.308 \\
(3.989)\end{array}$ \\
\hline DCPS & $\begin{array}{c}1.139 * * * \\
(0.331)\end{array}$ & $\begin{array}{c}0.111 \\
(0.0705)\end{array}$ & $\begin{array}{c}25.22 * * * \\
(2.954)\end{array}$ & $\begin{array}{c}39.08^{* * *} \\
(4.717)\end{array}$ & $\begin{array}{c}3.540 * * * \\
(0.515)\end{array}$ & $\begin{array}{c}0.364^{* * *} \\
(0.113)\end{array}$ & $\begin{array}{c}24.79 * * * \\
(1.732)\end{array}$ & $\begin{array}{c}31.21^{* * *} \\
(3.014)\end{array}$ \\
\hline CBL & $\begin{array}{c}3.74 \times 10^{-8 * * *} \\
\left(5.33 \times 10^{-9}\right)\end{array}$ & $\begin{array}{l}7.09 \times 10^{-9} * * * \\
\left(8.72 \times 10^{-10}\right)\end{array}$ & $\begin{array}{c}2.98 \times 10^{-8 * * *} \\
\left(9.27 \times 10^{-9}\right)\end{array}$ & $\begin{array}{c}1.98 \times 10^{-8 * * *} \\
\left(5.63 \times 10^{-9}\right)\end{array}$ & & & $\begin{array}{c}3.24 \times 10^{-8 * * *} \\
\left(6.48 \times 10^{-9}\right)\end{array}$ & $\begin{array}{c}1.73 \times 10^{-8 * * *} \\
\left(4.05 \times 10^{-9}\right)\end{array}$ \\
\hline Constant & $\begin{array}{c}2.978 \\
(8.052)\end{array}$ & $\begin{array}{l}15.26^{* *} \\
(7.160)\end{array}$ & $\begin{array}{c}340.1 \\
(325.7)\end{array}$ & $\begin{array}{c}-1667^{* *} \\
(760.1)\end{array}$ & $\begin{array}{c}280.7 * * * \\
(92.47)\end{array}$ & $\begin{array}{c}334.1 * * * \\
(118.0)\end{array}$ & $\begin{array}{c}42.27 \\
(149.1)\end{array}$ & $\begin{array}{c}-629.4^{* *} \\
(255.9)\end{array}$ \\
\hline $\mathrm{R}^{2}$ & & 0.571 & & 0.311 & & 0.310 & & 0.384 \\
\hline Obs. & 320 & 320 & 321 & 321 & 297 & 297 & 938 & 938 \\
\hline $\begin{array}{l}\mathrm{Chi}^{2} \\
(\mathrm{P}-\mathrm{v})\end{array}$ & 0.0000 & 0.0000 & 0.0000 & 0.0000 & 0.0000 & 0.0000 & 0.0000 & 0.0000 \\
\hline
\end{tabular}

Standard errors in parentheses ${ }^{* *} p<0.01,{ }^{* *} p<0.05,{ }^{*} p<0.1$.

Table 4 reports the FGLS and random effects results for the effect of BFSA on total carbon emissions for developing, emerging, and developed economies. A higher deposit rate (DR) has always been more beneficial to savers while higher lending rates (LR) and RR are usually negative outcomes for borrowers. However, we see that for the developing and emerging economies, DR and RR are strongly negatively correlated with total carbon emissions. This indicates that the higher the deposit rates offered to savers, the lower the total annual $\mathrm{CO}_{2}$ emissions. A higher deposit rate contributes to the alleviation (reduction) of $\mathrm{CO}_{2}$ emissions. The reason for this could be because the higher the deposit rates offered; the more people feel encouraged to save. Thus, the more they save, the less they spend on carbon-emitting products. We also see similar effects for $\mathrm{RR}$ and total $\mathrm{CO}_{2}$ emissions. Similarly, for developing economies, a strong negative correlation between the real interest rate and total carbon emissions is evident. Yet, domestic credit to the private sector (DCPS) for all economies shows a strong positive correlation. This indicates that increased investment into the private sector by banks and other such institutions contributes towards aggravating (increasing) total carbon emissions. This finding is in agreement with existing literature on emerging economies that found that increased domestic credit to the private sector tends to increase carbon emissions [48]. The same is the case for commercial bank lending for both developing and emerging economies. An increase in commercial bank lending indicates an increase in total carbon emissions. Higher deposit rates especially in developing and emerging economies remain an attractive incentive for bank savers [49]. With increased savings, banks have more funds available to invest in businesses and to lend out to borrowers [50]. Beyond simply investing in profitable businesses, green businesses are also seeing a rise in interest from banks and other kinds of investors [51]. Our findings on the effect of the banking and financial system activities on total carbon emissions are therefore understandable. Overall, for all economic types, higher deposit rates offered to savers contribute to reduced total carbon emissions while an increase in domestic credit to the private sector and commercial bank lending ultimately leads to an aggravation of total carbon emissions.

The estimation results for the effect of the banking and financial system activities on per capita carbon emissions for all economic types are found in Table 5. 
Table 5. Effect of banking and financial system activities on total per capita $\mathrm{CO}_{2}$ emissions.

\begin{tabular}{|c|c|c|c|c|c|c|c|c|}
\hline Variables & (1) & (2) & (3) & (4) & (5) & (6) & (7) & (8) \\
\hline & DPE & & $\mathrm{EE}$ & & DE & & $\mathrm{AE}$ & \\
\hline & FGLS & RE & FGLS & RE & FGLS & RE & FGLS & RE \\
\hline LR & $\begin{array}{l}-0.00495 \\
(0.00302)\end{array}$ & $\begin{array}{c}-0.000167 \\
(0.00183)\end{array}$ & $\begin{array}{l}0.0867^{* *} \\
(0.0388)\end{array}$ & $\begin{array}{c}0.0860^{* * *} \\
(0.0173)\end{array}$ & $\begin{array}{l}-0.187 \\
(0.204)\end{array}$ & $\begin{array}{l}-0.0650 \\
(0.0721)\end{array}$ & $\begin{array}{c}0.0191 \\
(0.0158)\end{array}$ & $\begin{array}{c}0.0176^{* * *} \\
(0.00600)\end{array}$ \\
\hline DR & $\begin{array}{c}0.00268 \\
(0.00527)\end{array}$ & $\begin{array}{c}4.06 \times 10^{-6} \\
(0.00296)\end{array}$ & $\begin{array}{l}-0.104^{*} \\
(0.0540)\end{array}$ & $\begin{array}{c}-0.100 * * * \\
(0.0201)\end{array}$ & $\begin{array}{l}0.375^{*} \\
(0.205)\end{array}$ & $\begin{array}{c}0.0899 \\
(0.0787)\end{array}$ & $\begin{array}{l}-0.0108 \\
(0.0264)\end{array}$ & $\begin{array}{c}-0.0251^{* * *} \\
(0.00805)\end{array}$ \\
\hline $\mathrm{RR}$ & $\begin{array}{l}0.000264 \\
(0.00197)\end{array}$ & $\begin{array}{c}0.000826 \\
(0.000972)\end{array}$ & $\begin{array}{c}-0.100 * * * \\
(0.0284)\end{array}$ & $\begin{array}{c}-0.0310^{* * *} \\
(0.00727)\end{array}$ & $\begin{array}{c}-0.250 * * \\
(0.123)\end{array}$ & $\begin{array}{c}-0.0541 \text { ** } \\
(0.0260)\end{array}$ & $\begin{array}{c}-0.0366^{* * *} \\
(0.0112)\end{array}$ & $\begin{array}{c}-0.00786^{* * *} \\
(0.00301)\end{array}$ \\
\hline DCPS & $\begin{array}{c}0.0292^{* * *} \\
(0.00321)\end{array}$ & $\begin{array}{c}0.00618^{* * *} \\
(0.00207)\end{array}$ & $\begin{array}{c}0.0409^{* * *} \\
(0.00468)\end{array}$ & $\begin{array}{c}0.0320^{* * *} \\
(0.00346)\end{array}$ & $\begin{array}{c}-0.0185^{* * *} \\
(0.00665)\end{array}$ & $\begin{array}{c}0.00877^{* * *} \\
(0.00243)\end{array}$ & $\begin{array}{l}0.0511^{* * *} \\
(0.00290)\end{array}$ & $\begin{array}{c}0.0274^{* * *} \\
(0.00246)\end{array}$ \\
\hline CBL & $\begin{array}{l}9.47 \times 10^{-11 *} \\
\left(5.17 \times 10^{-11}\right)\end{array}$ & $\begin{array}{c}2.88 \times 10^{-11} \\
\left(2.57 \times 10^{-11}\right)\end{array}$ & $\begin{array}{c}4.56 \times 10^{-11} \\
* * * \\
\left(1.47 \times 10^{-11}\right)\end{array}$ & $\begin{array}{c}1.65 \times 10^{-11} \\
* * * \\
\left(4.04 \times 10^{-12}\right)\end{array}$ & & & $\begin{array}{l}6.15 \times 10^{-11} \\
* * * \\
(0.0029044)\end{array}$ & $\begin{array}{c}1.60 \times 10^{-11} \\
* * * \\
\left(3.07 \times 10^{-12}\right)\end{array}$ \\
\hline Constant & $\begin{array}{l}-0.0198 \\
(0.0781)\end{array}$ & $\begin{array}{c}0.310^{* * *} \\
(0.109)\end{array}$ & $\begin{array}{c}1.597^{* * *} \\
(0.516)\end{array}$ & $\begin{array}{l}1.996^{*} \\
(1.060)\end{array}$ & $\begin{array}{c}14.43 * * * \\
(1.194)\end{array}$ & $\begin{array}{c}9.741^{* * *} \\
(1.466)\end{array}$ & $\begin{array}{c}0.265 \\
(0.250)\end{array}$ & $\begin{array}{c}1.051^{* * *} \\
(0.383)\end{array}$ \\
\hline $\mathrm{R}^{2}$ & & 0.359 & & 0.391 & & 0.114 & & 0.466 \\
\hline Obs. & 320 & 320 & 321 & 321 & 297 & 297 & 938 & 938 \\
\hline $\begin{array}{l}\mathrm{Chi}^{2} \\
(\mathrm{P}-\mathrm{v})\end{array}$ & 0.0000 & 0.0000 & 0.0000 & 0.0000 & 0.0000 & 0.0000 & 0.0000 & 0.0000 \\
\hline
\end{tabular}

Standard errors in parentheses ${ }^{* * *} p<0.01,{ }^{* *} p<0.05,{ }^{*} p<0.1$.

The FGLS and random effects result for the effect of banking system activities on per capita $\mathrm{CO}_{2}$ emissions for all economic types can be seen in Table 5. No significant effects exist for the developing economies in terms of lending rate, deposit rate, and real interest rate. Yet, for the emerging economies, there is a strong positive correlation for lending rate and a strong negative correlation for deposit rate, real interest rate, and per capita carbon emissions. Developed economies also show a strong negative correlation between real interest rate and per capita emissions. These findings indicate that in emerging economies, higher deposit rate offerings contribute towards alleviation of per capita carbon emissions. This is also the case for real interest rate, where an increase in RR contributes towards alleviation of carbon emissions in emerging and developed economies. This finding is in agreement with the study of Samour et al. [18], which found that an increase in real interest rate leads to a decrease in carbon emissions. Interestingly, for developing and emerging economies, DCPS and CBL show positive correlations with per capita carbon emissions. This indicates that for these two economic types, an increase in credit offered to the private sector contributes to the aggravation of per capita carbon emissions. Yet, this is not the case for developed economies in terms of domestic credit offered to the private sector where we see a strong negative correlation. This indicates that for the developed economies, increased credit to the private sector contributes to the reduction of per capita carbon emissions. This finding for developed economies falls in line with prior research which found that environmental sustainability consciousness is much higher in the developed economies as compared to developing economies. Stock markets are found to more often reallocate investments towards a greener and less polluting sectors [52].

The FGLS and random effects estimation results of the effect of the banking and financial system activities on total carbon emissions by the power industry for all economic types are reported in Table 6 .

The power industry, and the process of electricity generation through time has been known to be one of the largest perpetrators of carbon emissions in all economic types. Thus, the pressure and expectation to reduce carbon emissions have been placed heavily on the power industries. Power industries are now pushing towards reducing pollution and emission in the electricity generation process, and are striving towards adding more renewable energy sources such as solar, wind, hydro, natural gas into the electricity generation portfolio especially in the developed economies $[53,54]$. Table 6 reports the estimation results for the effect of banking system activities on carbon emissions by the power industry for all the economic types. Our estimation results show that for the developing economies, DR and RR have a strong negative correlation to carbon emissions by the power industry. This is also the case for emerging economies in terms of DR. The opposite is, however, the case for developed economies, whereby a significant positive correlation is evident between DR and carbon emissions by the power industry. This indicates that for the developing and emerging economies, an 
increase in DR contributes towards alleviating carbon emissions by the power industries while for the developed economies an increase leads to further aggravation of carbon emissions by the industry. Interestingly, for the developed economies, a strong negative correlation exists between the lending rate and carbon emissions. This indicates that the higher the lending rate, the lower the carbon emissions by the power industry. In the developed economies, the bank lending rate is consistently low sometimes ranging from 0.5 to $5 \%$, as compared to the developing and emerging economies who see rates from $6 \%$ to as much as $30 \%$ [36]. These lower levels of lending rates contribute to easier access to finance from banks for all borrowers, be they individuals, MSMEs owners, or large corporations. With this relative ease of finance access, it is understandable that lower interest rates contribute to increased rather than decreased carbon emissions by the power industries. Meanwhile, an increase in DCPS and CBL in all economies leads to the aggravation of the carbon emissions by the power industry. Considering that over 70\% of global power production still comes from fossil fuel sources [55], it is unsurprising that continued investment in the private sector and increase overall bank lending to borrowers, both individuals and organizations alike amount to an increase of carbon emissions by the power industry.

Table 7 reports the FGLS and random effects estimation results of the effect of the banking and financial system activities on total carbon emissions by buildings.

Table 6. Effect of banking and financial system on total $\mathrm{CO}_{2}$ emissions by the power industry.

\begin{tabular}{|c|c|c|c|c|c|c|c|c|}
\hline Variables & (1) & (2) & (3) & (4) & (5) & (6) & (7) & (8) \\
\hline & DPE & & $\mathrm{EE}$ & & DE & & $\mathrm{AE}$ & \\
\hline & FGLS & RE & FGLS & RE & FGLS & RE & FGLS & RE \\
\hline LR & $\begin{array}{c}0.146^{*} \\
(0.0857)\end{array}$ & $\begin{array}{c}-0.00320 \\
(0.0171)\end{array}$ & $\begin{array}{c}6.974 \\
(9.814)\end{array}$ & $\begin{array}{c}43.09 * * * \\
(10.07)\end{array}$ & $\begin{array}{c}-170.1^{* * *} \\
(29.61)\end{array}$ & $\begin{array}{l}-5.889 \\
(6.982)\end{array}$ & $\begin{array}{c}2.582 \\
(3.803)\end{array}$ & $\begin{array}{l}8.759 * * * \\
(3.356)\end{array}$ \\
\hline DR & $\begin{array}{c}-0.348^{* *} \\
(0.150)\end{array}$ & $\begin{array}{l}0.00194 \\
(0.0275)\end{array}$ & $\begin{array}{c}-38.31^{* * *} \\
(13.65)\end{array}$ & $\begin{array}{c}-48.14^{* * *} \\
(11.84)\end{array}$ & $\begin{array}{c}151.6^{* * *} \\
(29.85)\end{array}$ & $\begin{array}{l}-0.107 \\
(7.627)\end{array}$ & $\begin{array}{c}-19.61 * * * \\
(6.339)\end{array}$ & $\begin{array}{c}-10.61 * * \\
(4.598)\end{array}$ \\
\hline RR & $\begin{array}{c}-0.112^{* *} \\
(0.0559)\end{array}$ & $\begin{array}{c}0.0176^{*} \\
(0.00902)\end{array}$ & $\begin{array}{l}-10.36 \\
(7.193)\end{array}$ & $\begin{array}{c}-8.368^{*} \\
(4.426)\end{array}$ & $\begin{array}{l}34.26^{*} \\
(17.86)\end{array}$ & $\begin{array}{c}2.354 \\
(2.516)\end{array}$ & $\begin{array}{c}-4.474^{*} \\
(2.701)\end{array}$ & $\begin{array}{l}-1.897 \\
(1.735)\end{array}$ \\
\hline DCPS & $\begin{array}{l}0.309^{* * *} \\
(0.0913)\end{array}$ & $\begin{array}{l}0.00532 \\
(0.0193)\end{array}$ & $\begin{array}{c}10.20^{* * *} \\
(1.183)\end{array}$ & $\begin{array}{c}16.82^{* * *} \\
(2.017)\end{array}$ & $\begin{array}{c}7.649 * * * \\
(0.966)\end{array}$ & $\begin{array}{l}0.531^{* *} \\
(0.235)\end{array}$ & $\begin{array}{c}9.865^{* * *} \\
(0.698)\end{array}$ & $\begin{array}{c}13.28^{* * *} \\
(1.276)\end{array}$ \\
\hline CBL & $\begin{array}{c}1.03 \times 10^{-8 * * *} \\
\left(1.47 \times 10^{-9}\right)\end{array}$ & $\begin{array}{l}1.86 \times 10^{-9 * * *} \\
\left(2.39 \times 10^{-10}\right)\end{array}$ & $\begin{array}{c}1.27 \times 10^{-8 * * *} \\
\left(3.71 \times 10^{-9}\right)\end{array}$ & $\begin{array}{c}8.56 \times 10^{-9} * * * \\
\left(2.44 \times 10^{-9}\right)\end{array}$ & & & $\begin{array}{c}1.36 \times 10^{-8 * * *} \\
\left(2.61 \times 10^{-9}\right)\end{array}$ & $\begin{array}{c}7.56 \times 10^{-9 * * *} \\
\left(1.76 \times 10^{-9}\right)\end{array}$ \\
\hline Constant & $\begin{array}{c}0.175 \\
(2.220)\end{array}$ & $\begin{array}{l}4.208^{* *} \\
(1.740)\end{array}$ & $\begin{array}{c}148.9 \\
(130.4)\end{array}$ & $\begin{array}{c}-749.9 * * * \\
(285.9)\end{array}$ & $\begin{array}{l}-115.9 \\
(173.5)\end{array}$ & $\begin{array}{c}246.4 \\
(209.2)\end{array}$ & $\begin{array}{c}33.71 \\
(60.11)\end{array}$ & $\begin{array}{c}-277.8^{* * *} \\
(101.2)\end{array}$ \\
\hline $\mathrm{R}^{2}$ & & 0.738 & & 0.322 & & 0.301 & & 0.381 \\
\hline Obs. & 320 & 320 & 321 & 321 & 297 & 297 & 938 & 938 \\
\hline $\begin{array}{l}\mathrm{Chi}^{2} \\
(\mathrm{P}-\mathrm{v})\end{array}$ & 0.0000 & 0.0000 & 0.0000 & 0.0000 & 0.0000 & 0.0000 & 0.0000 & 0.0000 \\
\hline
\end{tabular}

Standard errors in parentheses ${ }^{* * *} p<0.01,{ }^{* *} p<0.05, * p<0.1$.

Table 7. Effect of banking and financial system on total $\mathrm{CO}_{2}$ emissions by buildings.

\begin{tabular}{|c|c|c|c|c|c|c|c|c|}
\hline Variables & (1) & (2) & (3) & (4) & (5) & (6) & (7) & (8) \\
\hline & DPE & & $\mathrm{EE}$ & & DE & & $\mathrm{AE}$ & \\
\hline & FGLS & RE & FGLS & RE & FGLS & RE & FGLS & RE \\
\hline LR & $\begin{array}{c}0.0462 \\
(0.0350)\end{array}$ & $\begin{array}{c}-0.00790 \\
(0.0104)\end{array}$ & $\begin{array}{c}1.236 \\
(1.877)\end{array}$ & $\begin{array}{c}3.008^{* * *} \\
(0.881)\end{array}$ & $\begin{array}{c}-16.76^{* * *} \\
(2.036)\end{array}$ & $\begin{array}{c}-0.0510 \\
(0.544)\end{array}$ & $\begin{array}{c}0.529 \\
(0.722)\end{array}$ & $\begin{array}{l}0.650 * * \\
(0.286)\end{array}$ \\
\hline DR & $\begin{array}{l}-0.133^{* *} \\
(0.0611)\end{array}$ & $\begin{array}{l}0.00560 \\
(0.0168)\end{array}$ & $\begin{array}{c}-6.318^{* *} \\
(2.611)\end{array}$ & $\begin{array}{c}-2.784^{* * *} \\
(1.024)\end{array}$ & $\begin{array}{c}17.79 * * * \\
(2.052)\end{array}$ & $\begin{array}{l}-0.134 \\
(0.595)\end{array}$ & $\begin{array}{c}-3.081^{* *} \\
(1.204)\end{array}$ & $\begin{array}{l}-0.409 \\
(0.384)\end{array}$ \\
\hline RR & $\begin{array}{c}-0.0423 * \\
(0.0228)\end{array}$ & $\begin{array}{l}0.00955^{*} \\
(0.00551)\end{array}$ & $\begin{array}{l}-1.859 \\
(1.376)\end{array}$ & $\begin{array}{c}-0.781 \text { ** } \\
(0.370)\end{array}$ & $\begin{array}{l}1.035 \\
(1.228)\end{array}$ & $\begin{array}{c}0.437^{* *} \\
(0.196)\end{array}$ & $\begin{array}{c}-0.879 * \\
(0.513)\end{array}$ & $\begin{array}{l}-0.178 \\
(0.143)\end{array}$ \\
\hline DCPS & $\begin{array}{l}0.120^{* * *} \\
(0.0372)\end{array}$ & $\begin{array}{c}-0.00784 \\
(0.0118)\end{array}$ & $\begin{array}{c}1.847^{* * *} \\
(0.226)\end{array}$ & $\begin{array}{c}1.136 * * * \\
(0.176)\end{array}$ & $\begin{array}{l}0.373 * * * \\
(0.0664)\end{array}$ & $\begin{array}{c}0.0256 \\
(0.0183)\end{array}$ & $\begin{array}{c}1.920 * * * \\
(0.133)\end{array}$ & $\begin{array}{c}0.941^{* * *} \\
(0.118)\end{array}$ \\
\hline CBL & $4.21 \times 10^{-9 * * *}$ & $\underbrace{8.91 \times 10^{-10}}_{* * *}$ & $1.83 \times 10^{-9} * * *$ & $\underset{* * *}{6.21 \times 10^{-10}}$ & & & $2.08 \times 10^{-9 * * *}$ & $\underset{* * *}{5.54} \times 10^{-10}$ \\
\hline Constant & $\begin{array}{c}\left(5.99 \times 10^{-10}\right) \\
0.415 \\
(0.906)\end{array}$ & $\begin{array}{c}\left(1.46 \times 10^{-10}\right) \\
1.920^{* *} \\
(0.839)\end{array}$ & $\begin{array}{c}\left(7.10 \times 10^{-10}\right) \\
40.39 \\
(24.94)\end{array}$ & $\begin{array}{c}\left(2.06 \times 10^{-10}\right) \\
8.635 \\
(57.42)\end{array}$ & $\begin{array}{c}45.12 * * * \\
(11.93)\end{array}$ & $\begin{array}{c}40.57^{* * *} \\
(15.32)\end{array}$ & $\begin{array}{c}\left(4.96 \times 10^{-10}\right) \\
6.484 \\
(11.41)\end{array}$ & $\begin{array}{c}\left(1.46 \times 10^{-10}\right) \\
3.830 \\
(18.89)\end{array}$ \\
\hline $\mathrm{R}^{2}$ & & 0.588 & & 0.208 & & 0.031 & & 0.402 \\
\hline Obs. & 320 & 320 & 321 & 321 & 297 & 297 & 938 & 938 \\
\hline $\begin{array}{l}\mathrm{Chi}^{2} \\
(\mathrm{P}-\mathrm{v})\end{array}$ & 0.0000 & 0.0000 & 0.0000 & 0.0000 & 0.0000 & 0.0000 & 0.0000 & 0.0000 \\
\hline
\end{tabular}


Carbon emissions by buildings have continually been an issue in the fight for environmental sustainability. Carbon inefficient buildings and construction account for as much as $28 \%$ of the total global energy-related carbon emissions [56]. Meanwhile, commercial and residential structures account for as much as $12 \%$ of total Greenhouse gas (GHG) emissions. Additionally, low-carbon buildings are now the preferred building style in most developed economies, and some emerging economies [57]. In several cases, energy-efficient and low-carbon buildings are being financed by green bonds, such as in Japan's case, where banks dominate green bond issuance [58]. Our estimation results on the effect of banking and financial system activities on carbon emissions by buildings in Table 7 show that for the developed economies, the lending rate and carbon emissions are significantly negatively correlated. As the lending rate is persistently low in developed economies, access to finance is better for borrowers, both individuals and businesses. Our findings reveal that lower lending rates in developed economies can contribute to higher carbon emissions by buildings. For all economic types, deposit rate and carbon emissions by buildings are significantly negatively correlated. This indicates that an increase in the deposit rate offered to savers can be associated with a decrease in carbon emissions by buildings in these economies. This is similar to the case for the effect of banking system activities on total carbon emissions. Additionally, for all economies, an increase in DCPS and CBL all have strong positive correlations with carbon emissions by buildings. This indicates that higher lending to the private sector and borrowers leads to an increase in carbon emissions by buildings.

The FGLS and random effects estimation results of the effect of banking and financial system activities on carbon emissions by the transportation sectors in the three economic types are shown in Table 8.

The transport sector remains one of the largest culprits of $\mathrm{CO}_{2}$ emission aggravation on a global scale. The transportation sector makes up as much as $28 \%$ of the global GHG emissions while industry and electricity and agriculture make up $22 \%, 27 \%$, and $10 \%$ of total GHG emissions in the United States [59]. Great effort is being directed towards curbing emissions by the transport sector while maintaining economic development in most of the economic types more especially in the emerging and developed economies. One key method is to evolve the public transportation system and use renewable energy sources to power them, such as in Hong Kong and China's case [60]. According to Table 8, our estimation results show that while lending rate and carbon emissions by the transport sector in emerging economies are positively correlated, it is significantly negatively correlated in the developed economies, and insignificantly correlated for developing economies. This indicates that in the emerging economies, a higher lending rate leads to an aggravation of carbon emissions by the transport sector. Meanwhile, in the developed economies, higher lending rates lead to reduced carbon emissions by the transport sector. In the emerging economies, pollution and emissions by the transportation sector are difficult to curb. This is because these economies are often highly reliant on transportation logistics to successfully achieve economic expansion. The deposit rate in all economic types is significantly negatively correlated with carbon emissions by the transport sector. This indicates that an increased deposit rate contributes towards alleviating carbon emissions. Yet, similar to the findings in Tables 3-6, DCPS, and CBL increase leads to an aggravation of carbon emissions. In this case, the greater the lending to the private sector by banks, the higher the carbon emissions by the transport sector.

The FGLS and random effects estimation results for the effect of banking and financial system activities on carbon emissions by other combustion industries for all three economic types are reported in Table 9.

As seen in Table 9, carbon emissions by other combustion industries and deposit rates have a significant negative correlation for developing and emerging economies. Domestic credit offered to the private sector is strongly positively correlated for all three economic types. This indicates that higher lending to the private sector is contributing to higher carbon emissions by other combustion industries. Additionally, for the developing and emerging economies, higher commercial bank lending is also strongly positively correlated with carbon emissions by other combustion industries. These findings are in agreement with the previous findings through Tables 4-8. Although the emerging 
and developed economies continually put great efforts towards curbing carbon emissions by the combustion industries [61], our results show that this reduction is not particularly evident when considering the effect of DCPS and CBL on combustion industry emissions. The greater the lending to the private sector, the higher the carbon emissions by these industries.

Table 8. Effect of banking and financial system on total $\mathrm{CO}_{2}$ emissions by transport sector.

\begin{tabular}{|c|c|c|c|c|c|c|c|c|}
\hline Variables & (1) & (2) & (3) & (4) & (5) & (6) & (7) & (8) \\
\hline & DPE & & EE & & DE & & $\mathrm{AE}$ & \\
\hline & FGLS & RE & FGLS & RE & FGLS & RE & FGLS & RE \\
\hline LR & $\begin{array}{c}0.0790 \\
(0.0693)\end{array}$ & $\begin{array}{l}-0.0377 \\
(0.0232)\end{array}$ & $\begin{array}{c}3.792 * * \\
(1.676)\end{array}$ & $\begin{array}{c}7.025^{* * *} \\
(1.796)\end{array}$ & $\begin{array}{c}-20.68^{* * *} \\
(3.288)\end{array}$ & $\begin{array}{l}-0.666 \\
(0.817)\end{array}$ & $\begin{array}{l}1.674^{* *} \\
(0.652)\end{array}$ & $\begin{array}{c}1.560^{* * *} \\
(0.602)\end{array}$ \\
\hline DR & $\begin{array}{c}-0.320^{* * *} \\
(0.121)\end{array}$ & $\begin{array}{l}0.00368 \\
(0.0375)\end{array}$ & $\begin{array}{c}-9.578^{* * *} \\
(2.332)\end{array}$ & $\begin{array}{c}-8.768^{* * *} \\
(2.126)\end{array}$ & $\begin{array}{c}20.60^{* * *} \\
(3.315)\end{array}$ & $\begin{array}{l}-0.676 \\
(0.893)\end{array}$ & $\begin{array}{c}-4.222^{* * *} \\
(1.087)\end{array}$ & $\begin{array}{c}-2.436^{* * *} \\
(0.838)\end{array}$ \\
\hline RR & $\begin{array}{c}-0.08944^{* *} \\
(0.0452)\end{array}$ & $\begin{array}{l}0.0276^{* *} \\
(0.0123)\end{array}$ & $\begin{array}{l}-1.587 \\
(1.229)\end{array}$ & $\begin{array}{c}-1.527^{*} \\
(0.807)\end{array}$ & $\begin{array}{c}1.250 \\
(1.983)\end{array}$ & $\begin{array}{c}0.156 \\
(0.295)\end{array}$ & $\begin{array}{l}-0.638 \\
(0.463)\end{array}$ & $\begin{array}{l}-0.368 \\
(0.319)\end{array}$ \\
\hline DCPS & $\begin{array}{l}0.237^{* * *} \\
(0.0737)\end{array}$ & $\begin{array}{c}0.0587^{* *} \\
(0.0263)\end{array}$ & $\begin{array}{c}1.527^{* * *} \\
(0.202)\end{array}$ & $\begin{array}{c}3.197^{* * *} \\
(0.360)\end{array}$ & $\begin{array}{c}0.569 * * * \\
(0.107)\end{array}$ & $\begin{array}{l}0.106^{* * *} \\
(0.0275)\end{array}$ & $\begin{array}{c}1.763^{* * *} \\
(0.120)\end{array}$ & $\begin{array}{c}2.538^{* * *} \\
(0.217)\end{array}$ \\
\hline CBL & $\begin{array}{c}8.96 \times 10^{-9} * * * \\
\left(1.19 \times 10^{-9}\right)\end{array}$ & $\begin{array}{l}2.48 \times 10^{-9} * * * \\
\left(3.25 \times 10^{-10}\right)\end{array}$ & $\begin{array}{l}3.15 \times 10^{-9} * * * \\
\left(6.34 \times 10^{-10}\right)\end{array}$ & $\begin{array}{l}1.70 \times 10^{-9} * * * \\
\left(4.43 \times 10^{-10}\right)\end{array}$ & & & $\begin{array}{l}3.77 \times 10^{-9} * * * \\
\left(4.48 \times 10^{-10}\right)\end{array}$ & $\begin{array}{l}1.69 \times 10^{-9} * * * \\
\left(3.22 \times 10^{-10}\right)\end{array}$ \\
\hline Constant & $\begin{array}{c}2.509 \\
(1.794)\end{array}$ & $\begin{array}{l}4.181^{* *} \\
(1.832)\end{array}$ & $\begin{array}{l}54.42 \text { ** } \\
(22.27)\end{array}$ & $\begin{array}{c}-90.14^{* *} \\
(45.56)\end{array}$ & $\begin{array}{c}67.98^{* * *} \\
(19.27)\end{array}$ & $\begin{array}{l}62.30^{* *} \\
(24.56)\end{array}$ & $\begin{array}{c}6.916 \\
(10.31)\end{array}$ & $\begin{array}{c}-31.02 * * \\
(15.56)\end{array}$ \\
\hline $\mathrm{R}^{2}$ & & 0.275 & & 0.364 & & 0.231 & & 0.499 \\
\hline Obs. & 320 & 320 & 321 & 321 & 297 & 297 & 938 & 938 \\
\hline $\begin{array}{l}\mathrm{Chi}^{2} \\
(\mathrm{P}-\mathrm{v})\end{array}$ & 0.0000 & 0.0000 & 0.0000 & 0.0000 & 0.0000 & 0.0000 & 0.0000 & 0.0000 \\
\hline
\end{tabular}

Standard errors in parentheses ${ }^{* * *} p<0.01,{ }^{* *} p<0.05,{ }^{*} p<0.1$.

Table 9. Effect of banking and financial system on total $\mathrm{CO}_{2}$ emissions by other combustion industries.

\begin{tabular}{|c|c|c|c|c|c|c|c|}
\hline Variables & (1) & (2) & (3) & (4) & (6) & (7) & (8) \\
\hline & DPE & & $\mathrm{EE}$ & & DE & $\mathrm{AE}$ & \\
\hline & FGLS & RE & FGLS & $\mathbf{R E}$ & RE & FGLS & RE \\
\hline LR & $\begin{array}{c}0.139 * \\
(0.0821)\end{array}$ & $\begin{array}{c}-0.00111 \\
(0.0134)\end{array}$ & $\begin{array}{c}3.420 \\
(7.607)\end{array}$ & $\begin{array}{c}28.30 * * * \\
(7.078)\end{array}$ & $\begin{array}{c}5.880 \times 10^{9} \\
\left(7.623 \times 10^{9}\right)\end{array}$ & $\begin{array}{c}1.815 \\
(2.918)\end{array}$ & $\begin{array}{l}5.776^{* *} \\
(2.318)\end{array}$ \\
\hline DR & $\begin{array}{c}-0.317^{* *} \\
(0.143)\end{array}$ & $\begin{array}{c}-0.00396 \\
(0.0217)\end{array}$ & $\begin{array}{c}-22.86^{* *} \\
(10.58)\end{array}$ & $\begin{array}{c}-29.85^{* * *} \\
(8.271)\end{array}$ & $\begin{array}{c}-1.281 \times 10^{10} \\
\left(8.325 \times 10^{9}\right)\end{array}$ & $\begin{array}{c}-12.35^{* *} \\
(4.863)\end{array}$ & $\begin{array}{c}-5.771 * \\
(3.147)\end{array}$ \\
\hline RR & $\begin{array}{c}-0.117^{* *} \\
(0.0535)\end{array}$ & $\begin{array}{c}0.00942 \\
(0.00711)\end{array}$ & $\begin{array}{l}-4.870 \\
(5.575)\end{array}$ & $\begin{array}{c}-5.386^{*} \\
(3.038)\end{array}$ & $\begin{array}{c}9.640 \times 10^{8} \\
\left(2.756 \times 10^{9}\right)\end{array}$ & $\begin{array}{l}-2.355 \\
(2.072)\end{array}$ & $\begin{array}{l}-1.173 \\
(1.183)\end{array}$ \\
\hline DCPS & $\begin{array}{c}0.317^{* * *} \\
(0.0874)\end{array}$ & $\begin{array}{c}0.0528^{* * *} \\
(0.0152)\end{array}$ & $\begin{array}{c}7.705^{* * *} \\
(0.917)\end{array}$ & $\begin{array}{c}10.98^{* * *} \\
(1.418)\end{array}$ & $\begin{array}{c}1.055 \times 10^{9} * * * \\
\left(2.570 \times 10^{8}\right)\end{array}$ & $\begin{array}{c}7.377^{* * *} \\
(0.536)\end{array}$ & $\begin{array}{c}8.783^{* * *} \\
(0.909)\end{array}$ \\
\hline CBL & $\begin{array}{c}9.14 \times 10^{-9} * * * \\
\left(1.41 \times 10^{-9}\right)\end{array}$ & $\begin{array}{l}1.16 \times 10^{-9} * * * \\
\left(1.88 \times 10^{-10}\right)\end{array}$ & $\begin{array}{c}7.66 \times 10^{-9} * * * \\
\left(2.88 \times 10^{-9}\right)\end{array}$ & $\begin{array}{c}5.72 \times 10^{-9} * * * \\
\left(1.68 \times 10^{-9}\right)\end{array}$ & & $\begin{array}{c}8.05 \times 10^{-9} * * * \\
\left(2.00 \times 10^{-9}\right)\end{array}$ & $\begin{array}{r}4.93 \times 10^{-9 * * *} \\
\left(1.20 \times 10^{-9}\right)\end{array}$ \\
\hline Constant & $\begin{array}{l}-0.227 \\
(2.126)\end{array}$ & $\begin{array}{c}2.927 \\
(1.902)\end{array}$ & $\begin{array}{c}52.51 \\
(101.1)\end{array}$ & $\begin{array}{c}-501.5^{* *} \\
(253.2)\end{array}$ & $\begin{array}{c}1.181 \times 10^{11} \\
\left(1.103 \times 10^{11}\right)\end{array}$ & $\begin{array}{l}-6.664 \\
(46.11)\end{array}$ & $\begin{array}{c}-192.4^{* *} \\
(81.99)\end{array}$ \\
\hline $\mathrm{R}^{2}$ & & 0.391 & & 0.283 & 0.266 & & 0.396 \\
\hline Obs. & 320 & 320 & 321 & 321 & 297 & 297 & 938 \\
\hline $\begin{array}{l}\mathrm{Chi}^{2} \\
(\mathrm{P}-\mathrm{v})\end{array}$ & 0.0000 & 0.0000 & 0.0000 & 0.0000 & 0.0000 & 0.0000 & 0.0000 \\
\hline
\end{tabular}

Table 10 reports the FGLS and random effects estimation results for the effect of banking and financial system activities on carbon emissions by other sectors industries for all three economic types.

According to Table 10, the BFSA and carbon emissions nexus, LR, and emissions by other sectors are strongly negatively correlated for the developed economies. This finding is similar to the finding for the effect of BSA on emissions by the power industry and by buildings, whereby a lower interest rate leads to the aggravation of the carbon emissions situation in these economies. DR and carbon emissions by other sectors have a significantly negative correlation for all developing and emerging economies. However, for the developed economies, DR, and carbon emissions by other sectors are strongly positively correlated. This indicates that while DR has a positive effect on carbon emissions in developing emerging economies, the opposite is the case for developed economies, where all other sectors are considered. We also find similar effects for DCPS and CBL as those seen in the prior tables where an increase in DCPS and CBL leads to an increase in carbon emissions by the other sectors. This finding is highly significant, at a $99 \%$ confidence level. In essence, the developing economies 
benefit from higher rather than lower lending rates, and all economies contribute to higher carbon emissions as lending to the private sector increases

Table 10. Effect of banking and financial system on total $\mathrm{CO}_{2}$ emissions by other sectors.

\begin{tabular}{|c|c|c|c|c|c|c|c|c|}
\hline \multirow[t]{3}{*}{ Variables } & (1) & (2) & (3) & (4) & (5) & (6) & (7) & (8) \\
\hline & DPE & & EE & & DE & & $\mathrm{AE}$ & \\
\hline & FGLS & RE & FGLS & RE & FGLS & RE & FGLS & RE \\
\hline \multirow[t]{2}{*}{ LR } & 0.0598 & -0.00635 & 3.229 & $16.03^{* * *}$ & $-11.89^{* * *}$ & -0.963 & 1.364 & 3.293 ** \\
\hline & $(0.0414)$ & $(0.00914)$ & (3.931) & $(3.920)$ & (1.543) & $(1.223)$ & (1.509) & $(1.292)$ \\
\hline \multirow[t]{2}{*}{ DR } & $-0.144^{* *}$ & 0.0161 & $-14.08^{* *}$ & $-16.82^{* * *}$ & $12.31^{* * *}$ & 1.206 & $-7.077^{* * *}$ & $-3.278^{*}$ \\
\hline & $(0.0722)$ & $(0.0147)$ & $(5.469)$ & $(4.593)$ & $(1.555)$ & $(1.335)$ & $(2.516)$ & $(1.764)$ \\
\hline \multirow[t]{2}{*}{$\mathrm{RR}$} & -0.0490 * & 0.00768 & -3.483 & $-3.055^{*}$ & 0.842 & $-0.884^{* *}$ & -1.498 & -0.663 \\
\hline & $(0.0270)$ & $(0.00483)$ & $(2.881)$ & $(1.700)$ & $(0.931)$ & $(0.445)$ & $(1.072)$ & $(0.664)$ \\
\hline \multirow[t]{2}{*}{ DCPS } & $0.149^{* * *}$ & 0.00544 & $3.949 * * *$ & $6.527^{* * *}$ & $0.319^{* * *}$ & 0.00473 & $3.859^{* * *}$ & $5.157^{* * *}$ \\
\hline & $(0.0440)$ & $(0.0103)$ & $(0.474)$ & $(0.786)$ & $(0.0503)$ & $(0.0413)$ & $(0.277)$ & $(0.498)$ \\
\hline \multirow[t]{2}{*}{ CBL } & $4.74 \times 10^{-9 * * *}$ & $7.41 \times 10_{* * *}^{-10}$ & $4.46 \times 10^{-9 * * *}$ & $3.08 \times 10^{-9} * * *$ & & & $4.87 \times 10^{-9 * * *}$ & $2.68 \times 10^{-9 * * *}$ \\
\hline & $\left(7.08 \times 10^{-10}\right)$ & $\left(1.28 \times 10^{-10}\right)$ & $\left(1.49 \times 10^{-9}\right)$ & $\left(9.40 \times 10^{-10}\right)$ & & & $\left(1.04 \times 10^{-9}\right)$ & $\left(6.75 \times 10^{-10}\right)$ \\
\hline \multirow[t]{2}{*}{ Constant } & 0.154 & $1.988 * *$ & 43.95 & $-296.2 * *$ & $24.47^{* * *}$ & $32.24 * * *$ & 1.862 & $-112.9^{* * *}$ \\
\hline & $(1.071)$ & $(0.999)$ & $(52.23)$ & $(124.2)$ & $(9.039)$ & $(11.52)$ & (23.85) & $(41.20)$ \\
\hline $\mathrm{R}^{2}$ & & 0.532 & & 0.304 & & 0.187 & & 0.419 \\
\hline Obs. & 320 & 320 & 321 & 321 & 297 & 297 & 938 & 938 \\
\hline $\begin{array}{l}\mathrm{Chi}^{2} \\
(\mathrm{P}-\mathrm{v})\end{array}$ & 0.0000 & 0.0000 & 0.0000 & 0.0000 & 0.0000 & 0.0000 & 0.0000 & 0.0000 \\
\hline
\end{tabular}

Standard errors in parentheses ${ }^{* * *} p<0.01,{ }^{* *} p<0.05,{ }^{*} p<0.1$.

To ensure the robustness of our results, Table 11 provides the difference generalized method of moments estimation results for the effect of banking and financial system activities on all seven layers of carbon emissions, namely, total $\mathrm{CO}_{2}$ emissions, emissions per capita, emissions by the power industry, by buildings, by the transport sector, by the other combustion industries, and by the other sectors, for all economic types.

Table 11. All economies' difference gmm results for effect of BFSA on $\mathrm{CO}_{2}$ emissions.

\begin{tabular}{cccccccc}
\hline Variables & $\mathbf{( 1 )}$ & $\mathbf{( 2 )}$ & $\mathbf{( 3 )}$ & $\mathbf{( 4 )}$ & $\mathbf{( 5 )}$ & $\mathbf{( 6 )}$ & $\mathbf{( 7 )}$ \\
\hline & TC02 & CO2Pc & CO2PI & CO2B & CO2T & CO2OCI & CO2OS \\
\hline C02-L1 & $0.966^{* * *}$ & $0.910^{* * *}$ & $0.962^{* * *}$ & $0.820^{* * *}$ & $0.980^{* * *}$ & $0.945^{* * *}$ & $0.959^{* * *}$ \\
& $(0.0183)$ & $(0.0632)$ & $(0.0181)$ & $(0.0655)$ & $(0.0237)$ & $(0.0196)$ & $(0.0140)$ \\
LR & $8.502^{* *}$ & 0.0145 & $4.256^{* *}$ & 0.431 & $0.965^{* *}$ & $2.571^{*}$ & 0.679 \\
& $(4.316)$ & $(0.0109)$ & $(1.851)$ & $(0.605)$ & $(0.435)$ & $(1.412)$ & $(0.548)$ \\
DR & $-12.91^{* *}$ & -0.0259 & $-6.395^{* *}$ & -0.324 & $-1.781^{* * *}$ & -3.291 & -1.092 \\
& $(6.141)$ & $(0.0158)$ & $(2.630)$ & $(0.883)$ & $(0.622)$ & $(2.018)$ & $(0.779)$ \\
RR & $-3.672^{*}$ & -0.00751 & $-1.626^{*}$ & -0.132 & -0.273 & $-1.503^{* *}$ & -0.225 \\
& $(2.067)$ & $(0.00531)$ & $(0.878)$ & $(0.297)$ & $(0.210)$ & $(0.682)$ & $(0.262)$ \\
DCPS & -1.057 & -0.00115 & -0.315 & 0.282 & -0.0236 & -0.340 & -0.190 \\
& $(1.283)$ & $(0.00338)$ & $(0.543)$ & $(0.176)$ & $(0.143)$ & $(0.406)$ & $(0.165)$ \\
CBL & $1.75 \times 10^{-9 * *}$ & $2.71 \times 10^{-12}$ & $9.83 \times 10^{-10}$ & $5.50 \times 10^{-11}$ & $1.86 \times 10^{-10 * *}$ & $4.03 \times 10^{-10}$ & $2.22 \times 10^{-10 * *}$ \\
& $\left(8.33 \times 10^{-10}\right)$ & $\left(2.20 \times 10^{-12}\right)$ & $\left(3.54 \times 10^{-10}\right)$ & $\left(1.17 \times 10^{-10}\right)$ & $\left(8.37 \times 10^{-11}\right)$ & $\left(2.76 \times 10^{-10}\right)$ & $\left(1.05 \times 10^{-10}\right)$ \\
Obs. & 938 & 938 & 938 & 938 & 938 & 938 \\
Chi ${ }^{2}$ & 0.0000 & 0.0000 & 0.0000 & 0.0000 & 0.0000 & 0.0000 & 0.0000 \\
$(\mathrm{P}-\mathrm{v})$ & \multicolumn{7}{c}{ Standard errors in parentheses }
\end{tabular}

As a robustness measure, the difference generalized method of moments estimation approach is used to check the effect of BSFA on all seven layers of carbon emissions for all economic types. We not only aim to use an alternative econometric methodology, but we also address the potential endogeneity bias especially where the lending rates are concerned. The results of the Sargan test indicate that there are no over-identification issues in our estimations. Additionally, the results of the Arellano-Bond autocorrelation test for $\mathrm{AR}(1), \mathrm{AR}(2)$ all illustrate that the first-order autocorrelation is statistically significant, while the second-order is not significant. The results also show high-level persistence in the dependent variables. We find from the GMM estimation results that for all economies, deposit rate and total carbon emissions are negatively correlated. Additionally, CBL and carbon emissions are positively correlated. LR and CBL are significantly positively correlated, while DR is negatively correlated with carbon emissions by the power industry. As for emissions by the transport industry, LR and 
CBL are positively correlated while DR is negatively correlated. Where other sectors are concerned CBL and carbon emissions by the other sectors are positively correlated for all economies. All these findings are in agreement with the detailed findings and discussions made from the FGLS and RE estimation models.

Table 12. List of positive and negative findings by economic type towards $\mathrm{CO}_{2}$ emissions reduction.

\begin{tabular}{cc}
\hline Significant Positive Findings & Significant Negative Findings \\
\hline Developing Economies & Developing Economies \\
\hline
\end{tabular}

1. DR and RR increase amounts to decreased total $\mathrm{CO}_{2}$ emissions.

1. DCPS and CBL increase amounts to an increase in total $\mathrm{CO}_{2}$ emissions.

2. DR and RR increase amounts to decreased $\mathrm{CO}_{2}$ emissions by the power industry.

3. DR increase amounts to decreased $\mathrm{CO}_{2}$ emissions by the buildings.

4. DR and RR increase amounts to decreased $\mathrm{CO}_{2}$ emissions by the transport sector.

5. DR and RR increase amounts to decreased $\mathrm{CO}_{2}$ emissions by the other combustion industries.

6. DR increase amounts to decreased $\mathrm{CO}_{2}$ emissions by the other sectors.

2. DCPS increase amounts to an increase in per capita $\mathrm{CO}_{2}$ emissions.

3. DCPS and CBL increase amounts to an increase in $\mathrm{CO}_{2}$ emissions by the power industry.

4. DCPS and CBL increase amounts to an increase in $\mathrm{CO}_{2}$ emissions by the buildings.

5. DCPS and CBL increase amounts to an increase in $\mathrm{CO}_{2}$ emissions by the transport sector.

6. DCPS and CBL increase amounts to an increase in $\mathrm{CO}_{2}$ emissions by the other combustion industries.

7. DCPS and CBL increase amounts to an increase in $\mathrm{CO}_{2}$ emissions by the other sectors.

\section{Emerging Economies}

1. DR increase amounts to decreased total $\mathrm{CO}_{2}$ emissions.

2. $\mathrm{RR}$ increase amounts to decreased per capita $\mathrm{CO}_{2}$ emissions.

3. DR increase amounts to decreased $\mathrm{CO}_{2}$ emissions by the power industry.

4. DR increase amounts to decreased $\mathrm{CO}_{2}$ emissions by buildings.

5. DR increase amounts to decreased $\mathrm{CO}_{2}$ emissions by the transport sector.

6. DR increase amounts to decreased $\mathrm{CO}_{2}$ emissions by other combustion industries.

7. DR increase amounts to decreased $\mathrm{CO}_{2}$ emissions by other sectors.

\section{Emerging Economies}

1. DCPS and CBL increase amounts to an increase in total $\mathrm{CO}_{2}$ emissions.

2. DCPS and CBL increase amounts to an increase in per capita $\mathrm{CO}_{2}$ emissions.

3. DCPS and CBL increase amounts to an increase in $\mathrm{CO}_{2}$ emissions by the power industry.

4. DCPS and CBL increase amounts to an increase in $\mathrm{CO}_{2}$ emissions by the buildings.

5. LR, DCPS, and CBL increase amounts to an increase in $\mathrm{CO}_{2}$ emissions by the transport sector.

6. DCPS and CBL increase amounts to an increase in $\mathrm{CO}_{2}$ emissions by other combustion industries.

7. DCPS and CBL increase amounts to increased $\mathrm{CO}_{2}$ emissions by the other sectors.

\begin{tabular}{|c|c|c|}
\hline & Developed Economies & Developed Economies \\
\hline $\begin{array}{l}1 . \\
2 . \\
3 . \\
3 .\end{array}$ & $\begin{array}{l}\text { LR increase amounts to decreased total } \\
\mathrm{CO}_{2} \text { emissions. } \\
\mathrm{DR} \text { and DCPS increase amounts to decreased } \\
\text { per capita } \mathrm{CO}_{2} \text { emissions. } \\
\text { LR increase amounts to decreased } \mathrm{CO}_{2} \\
\text { emissions by the power industry. } \\
\text { LR increase amounts to decreased } \mathrm{CO}_{2} \\
\text { emissions by buildings. } \\
\text { LR increase amounts to decreased } \mathrm{CO}_{2} \\
\text { emissions by the transport sector. } \\
\text { LR increase amounts to decreased } \mathrm{CO}_{2} \\
\text { emissions by other sectors. }\end{array}$ & $\begin{array}{l}\text { 1. DR and DCPS increase amounts to an increase } \\
\text { in total } \mathrm{CO}_{2} \text { emissions. } \\
\text { 2. DR and DCPS increase amounts to an increase } \\
\text { in } \mathrm{CO}_{2} \text { emissions by the power industry. } \\
\text { 3. DR and DCPS increase amounts to an increase } \\
\text { in } \mathrm{CO}_{2} \text { emissions by buildings. } \\
\text { 4. DR and DCPS increase amounts to an increase } \\
\text { in } \mathrm{CO}_{2} \text { emissions by the transport sector. } \\
\text { 5. DR and DCPS increase amounts to an increase } \\
\text { in } \mathrm{CO}_{2} \text { emissions by other sectors. }\end{array}$ \\
\hline
\end{tabular}




\section{Conclusions and Policy Implications}

In the present study, we carefully analyzed the banking system and carbon emissions nexus towards achieving environmental sustainability. We did this by checking seven key layers of carbon emissions in three economic types, namely developing, emerging, and developed economies. Table 12 provides a detailed summary of all the main positive and negative findings made on the nexus for each of the economic types.

From our findings, three major trends can be noticed in the banking sector and carbon emissions nexus analysis for the three economic types. First, for the developing and emerging economies, a higher deposit rate contributes towards decreased carbon emissions, especially in total carbon emissions, emissions by the power industry, by buildings, transport, and other combustion industries. Additionally, increased domestic credit to the private sector and commercial bank lending consistently contributes to an aggravation of the carbon emissions situation. Second, for the developed economies, we observed a different trend, whereby an increased lending rate contributes to decreased carbon emissions especially in total carbon emissions, emissions by the power industry, by buildings, transport sector, and other sectors. Third, increased domestic credit to the private sector for all economic types consistently contributes to an increase in carbon emissions in all seven layers of carbon emissions.

For the banking sector to make a significant contribution to the reduction of carbon emissions, the following recommendations are offered. First, the developing and emerging economies are encouraged to improve and sustain higher deposit rates for savers, as this inadvertently contributes towards the overall reduction of carbon emissions by the transport sector, buildings, power industry, and other sectors. The reason for this is that the higher the deposit rates offered, the more people feel encouraged to save. Thus, the more they save, the less they spend on carbon dioxide emitting products. Second, these economies are encouraged to supervise domestic credit offered to the private sector, as well as overall commercial bank lending. The increase in these two variables consistently leads to higher carbon emissions. The banking sector in these economies is encouraged to lend less to carbon polluting businesses and more towards those who have greener initiatives in place, and who emit less.

Third, for the developed economies, the excessively low lending rates do not appear to be beneficial towards the achievement of environmental sustainability overall, especially in the reduction of carbon emissions. These economies are therefore encouraged to set up more barriers to the apparent ease of financing for the private sector, or higher supervision for the types of borrowers loaned to. Fourth, for all three economic types, higher domestic credit offered to the private sector shows a consistent contribution towards higher carbon emissions in all seven layers of carbon emissions. It is, therefore, apparent that the banking sector and all other financial institutions involved in lending to the private sector must supervise the types of businesses being lent to. If the banking and finance sector should successfully contribute towards carbon emissions reduction, then more financial lending opportunity should be granted to businesses with green initiatives, and those with low carbon emissions. Providing financing to high GHG emitting firms enables them to pollute more, which in turn leads to an aggravation of the carbon emissions situation. In essence, this renders efforts towards carbon emissions on all other levels futile.

This study is not without its limitations. The inferences made herein are limited to the data and the period upon which the findings are-based. As more datasets become available, this research can be replicated and extended. It can be expanded by using panel data of more countries belonging to each of the economic types. Further research is also required to know if the nexus between BFSA and carbon emissions is dependent on some specific economic growth factors in each economic type. The empirical analysis in this study should motivate similar studies for the remaining countries of the world.

Author Contributions: S.C.O. Conceptualized the research and carried out the formal analysis. O.B. supervised the study, and revised the design. E.O.-M. assisted with data curation and A.N.K.F. did the final revision and editing. All authors have read and agreed to the published version of the manuscript. 
Funding: This work was supported by the National Natural Science Foundation of China (Grant no. 71472025).

Conflicts of Interest: The authors declare no conflict of interest. The funders had no role in the design of the study; in the collection, analyses, or interpretation of data; in the writing of the manuscript, or in the decision to publish the results.

\section{Appendix A}

Table A1. List of countries used in study.

\begin{tabular}{ccc}
\hline Developing Economies & Emerging Economies & Developed Economies \\
\hline Madagascar & China & Switzerland \\
Benin & Brazil & Australia \\
The Gambia & Turkey & Sweden \\
Togo & Philippines & Singapore \\
Both Sudan & United Arab Emirates & Hong Kong \\
Uganda & Russia & Netherlands \\
Chad & India & Canada \\
Pakistan & Indonesia & United Kingdom \\
Myanmar & Nigeria & United States \\
Burkina Faso & Egypt & Japan \\
Tanzania & South Africa & Israel \\
Zimbabwe & Morocco & South Korea \\
Malawi & Tunisia & Belgium \\
Haiti & Argentina & Luxembourg \\
Ethiopia & Malaysia & Spain \\
\hline
\end{tabular}

\section{References}

1. Bamisile, O.; Huang, Q.; Xu, X.; Hu, W.; Liu, W.; Liu, Z.; Chen, Z. An approach for sustainable energy planning towards $100 \%$ electrification of Nigeria by 2030. Energy 2020, 197, 117172. [CrossRef]

2. Pontarollo, N.; Serpieri, C. Testing the Environmental Kuznets Curve hypothesis on land use: The case of Romania. Land Use Policy 2020, 97, 104695. [CrossRef]

3. Munir, Q.; Lean, H.H.; Smyth, R. $\mathrm{CO}_{2}$ emissions, energy consumption and economic growth in the ASEAN-5 countries: A cross-sectional dependence approach. Energy Econ. 2020, 85, 104571. [CrossRef]

4. Purcel, A.-A. New insights into the environmental Kuznets curve hypothesis in developing and transition economies: A literature survey. Environ. Econ. Policy Stud. 2020, 22, 1-47. [CrossRef]

5. Dong, K.; Hochman, G.; Timilsina, G. Do drivers of $\mathrm{CO}_{2}$ emission growth alter overtime and by the stage of economic development? Energy Policy 2020, 140, 111420. [CrossRef]

6. Aye, G.C.; Edoja, P.E. Effect of economic growth on $\mathrm{CO}_{2}$ emission in developing countries: Evidence from a dynamic panel threshold model. Cogent Econ. Finance 2017, 5, 1379239. [CrossRef]

7. Ridzuan, N.H.A.M.; Marwan, N.F.; Khalid, N.; Ali, M.H.; Tseng, M.-L. Effects of agriculture, renewable energy, and economic growth on carbon dioxide emissions: Evidence of the environmental Kuznets curve. Resour. Conserv. Recycl. 2020, 160, 104879. [CrossRef]

8. Saidi, K.; Omri, A. Reducing $\mathrm{CO}_{2}$ emissions in OECD countries: Do renewable and nuclear energy matter? Prog. Nucl. Energy 2020, 126, 103425. [CrossRef]

9. Apergis, N.; Ben Jebli, M.; Ben Youssef, S. Does renewable energy consumption and health expenditures decrease carbon dioxide emissions? Evidence for sub-Saharan Africa countries. Renew. Energy 2018, 127, 1011-1016. [CrossRef]

10. Nguyen, K.H.; Kakinaka, M. Renewable energy consumption, carbon emissions, and development stages: Some evidence from panel cointegration analysis. Renew. Energy 2019, 132, 1049-1057. [CrossRef]

11. Farhani, S.; Ozturk, I. Causal relationship between $\mathrm{CO}_{2}$ emissions, real GDP, energy consumption, financial development, trade openness, and urbanization in Tunisia. Environ. Sci. Pollut. Res. 2015, 22, 15663-15676. [CrossRef] [PubMed]

12. Zhao, B.; Yang, W. Does financial development influence $\mathrm{CO}_{2}$ emissions? A Chinese province-level study. Energy 2020, 200, 117523. [CrossRef] 
13. Kim, D.-H.; Wu, Y.-C.; Lin, S.-C. Carbon dioxide emissions and the finance curse. Energy Econ. $2020,88$. [CrossRef]

14. Blom, P. How Can Banks Help Steer the Transition to a Sustainable Economy? In Green Growth Knowledge Platform; 2019. Available online: https://www.greengrowthknowledge.org/blog/how-can-banks-help-steertransition-sustainable-economy (accessed on 10 September 2020).

15. Awodumi, O.B.; Adewuyi, A.O. The role of non-renewable energy consumption in economic growth and carbon emission: Evidence from oil producing economies in Africa. Energy Strat. Rev. 2020, 27, 100434. [CrossRef]

16. Zheng, J.; Sun, X.; Jia, L.; Zhou, Y. Electric passenger vehicles sales and carbon dioxide emission reduction potential in China's leading markets. J. Clean. Prod. 2020, 243, 118607. [CrossRef]

17. Yao, X.; Zhang, X.; Guo, Z. The tug of war between local government and enterprises in reducing China's carbon dioxide emissions intensity. Sci. Total. Environ. 2020, 710, 136140. [CrossRef] [PubMed]

18. Samour, A. Testing the impact of banking sector development on turkey's $\mathrm{CO}_{2}$ emissions. Appl. Ecol. Environ. Res. 2019, 17, 1-21. [CrossRef]

19. Sugiawan, Y.; Kurniawan, R.; Managi, S. Are carbon dioxide emission reductions compatible with sustainable well-being? Appl. Energy 2019, 242, 1-11. [CrossRef]

20. Cao, Y.; Shen, D. Contribution of shared bikes to carbon dioxide emission reduction and the economy in Beijing. Sustain. Cities Soc. 2019, 51. [CrossRef]

21. Du, K.; Li, P.; Yan, Z. Do green technology innovations contribute to carbon dioxide emission reduction? Empirical evidence from patent data. Technol. Forecast. Soc. Chang. 2019, 146, 297-303. [CrossRef]

22. Sarkodie, S.A.; Strezov, V. Empirical study of the Environmental Kuznets curve and Environmental Sustainability curve hypothesis for Australia, China, Ghana and USA. J. Clean. Prod. 2018, 201, 98-110. [CrossRef]

23. Chen, J.; Hu, T.E.; Van Tulder, R. Is the Environmental Kuznets Curve Still Valid: A Perspective of Wicked Problems. Sustainability 2019, 11, 4747. [CrossRef]

24. Wang, Y.; Sun, X.; Wangb, B.; Liua, X. Energy saving, GHG abatement and industrial growth in OECD countries: A green productivity approach. Energy 2020, 194, 116833. [CrossRef]

25. Kararach, G.; Nhamo, G.; Mubila, M.; Nhemachena, C.; Babu, S. Reflections on the Green Growth Index for developing countries: A focus of selected African countries. Dev. Policy Rev. 2017, 36, 432-435. [CrossRef]

26. Liu, X.; Mao, G.; Ren, J.; Li, R.Y.M.; Guo, J.; Zhang, H. How might China achieve its 2020 emissions target? A scenario analysis of energy consumption and CO 2 emissions using the system dynamics model. J. Clean. Prod. 2015, 103, 401-410. [CrossRef]

27. Wang, R.; Mirza, N.; Vasbieva, D.G.; Abbas, Q.; Xiong, D. The nexus of carbon emissions, financial development, renewable energy consumption, and technological innovation: What should be the priorities in light of COP 21 Agreements? J. Environ. Manag. 2020, 271, 111027. [CrossRef]

28. Kavya, T.; Shijin, S. Economic development, financial development, and income inequality nexus. Borsa Istanb. Rev. 2020, 20, 80-93. [CrossRef]

29. Van Eyden, R.; Difeto, M.; Gupta, R.; Wohar, M.E. Oil price volatility and economic growth: Evidence from advanced economies using more than a century's data. Appl. Energy 2019, 612-621. [CrossRef]

30. Phong, L.H. Globalization, financial development, and environmental degradation in the presence of environmental Kuznets curve: Evidence from ASEAN-5 countries. Int. J. Energy Econ. Policy 2019, 9, 40-50.

31. Le, T.-H.; Canh, N.P. Is energy security a driver for economic growth? Evidence from a global sample. Energy Policy 2019, 129, 436-451. [CrossRef]

32. Hashmi, R.; Alam, K. Dynamic relationship among environmental regulation, innovation, $\mathrm{CO}_{2}$ emissions, population, and economic growth in OECD countries: A panel investigation. J. Clean. Prod. 2019, 231, 1100-1109. [CrossRef]

33. Hansen, B.E. Threshold effects in non-dynamic panels: Estimation, testing, and inference. J. Econ. 1999, 93, 345-368. [CrossRef]

34. Sraders, A. Emerging Characteristics and List. 2020. Available online: https://www.thestreet.com/markets/ emerging-markets/what-are-emerging-markets-14819803 (accessed on 11 June 2020).

35. World Bank Statistics. $\mathrm{CO}_{2}$ Emissions (kt). 2020. Available online: https://data.worldbank.org/indicator/EN. ATM.CO2E.KT (accessed on 10 August 2020). 
36. International Monetary Fund. Lending Interst Rate \%. 2020. Available online: https://data.worldbank.org/ indicator/FR.INR.LEND (accessed on 9 June 2020).

37. WBS. Commercial banks and other Lending (PPG +PNG) (NFL, Current US\$). 2020. Available online: https://data.worldbank.org/indicator/DT.NFL.PCBO.CD (accessed on 9 June 2020).

38. International Monetary Fund. Deposit Interest Rate. 2020. Available online: https://data.worldbank.org/ indicator/FR.INR.DPST (accessed on 15 June 2020).

39. International Monetary Fund. Real Interest Rate. 2020. Available online: https://data.worldbank.org/ indicator/FR.INR.RINR (accessed on 15 July 2020).

40. International Monetary Fund. Bank Nonperforming Loans to Total Gross Loans (\%). 2020. Available online: https://data.worldbank.org/indicator/FB.AST.NPER.ZS (accessed on 10 June 2020).

41. International Monetary Fund. Domestic Credit to Private Sector by Banks. 2020. Available online: https://data.worldbank.org/indicator/FD.AST.PRVT.GD.ZS (accessed on 18 May 2020).

42. De Pascale, G.; Sardaro, R.; Faccilongo, N.; Contò, F. What is the influence of FDI and international people flows on environment and growth in OECD countries? A panel study. Environ. Impact Assess. Rev. 2020, 84, 106434. [CrossRef]

43. Olanrewaju, B.T.; Olubusoye, O.; Adenikinju, A.F.; Akintande, O. A panel data analysis of renewable energy consumption in Africa. Renew. Energy 2019, 140, 668-679. [CrossRef]

44. Ibrahim, M.; Alagidede, P. Effect of financial development on economic growth in sub-Saharan Africa. J. Policy Model. 2018, 40, 1104-1125. [CrossRef]

45. Aitken, A.C. IV.-On Least Squares and Linear Combination of Observations. Proc. R. Soc. Edinb. 1936, 55, 42-48. [CrossRef]

46. Miller, S.; Startz, R. Feasible Generalized Least Squares Using Machine Learning. SSRN Electron. J. 2017. [CrossRef]

47. Wooldridge, J.M. Correlated Random Effects Models. In Proceedings of the the 15th Conference on Panel Data, Bonn, Germany, 3-5 July 2009. Available online: http://econ.msu.edu/faculty/wooldridge/docs/cre1_r4.pdf (accessed on 28 September 2020).

48. Hove, S.; Türsoy, T. An investigation of the environmental Kuznets curve in emerging economies. J. Clean. Prod. 2019, 236. [CrossRef]

49. Wang, J.S.-H.; Ssewamala, F.M.; Neilands, T.B.; Bermudez, L.G.; Garfinkel, I.; Waldfogel, J.; Brooks-Gunn, J.; You, J. Effects of Financial Incentives on Saving Outcomes and Material Well-Being: Evidence From a Randomized Controlled Trial in Uganda. J. Policy Anal. Manag. 2018, 37, 602-629. [CrossRef]

50. Werner, R.A. How do banks create money, and why can other firms not do the same? An explanation for the coexistence of lending and deposit-taking. Int. Rev. Financ. Anal. 2014, 36, 71-77. [CrossRef]

51. OECD. Green Investment Banks: Policy Perspectives. Available online: https://www.oecdilibrary.org/docserver/e3c2526cen.pdf?expires $=1601431776 \&$ id =id\&accname=guest\&checksum $=$ 53165311EF8CE7BDFA9486550B8AC171 (accessed on 28 September 2020).

52. Popov, A. Handbook of Finance and Development; Edward Elgar Publishing: Lypiatts, UK, 2018; Chapter 3.

53. Carbon Dioxide Emissions in the Electricity Sector: Factors, Trends, and Projections. Available online: https://crsreports.congress.gov/product/pdf/R/R45453 (accessed on 30 September 2020).

54. Li, R.; Su, M. The Role of Natural Gas and Renewable Energy in Curbing Carbon Emission: Case Study of the United States. Sustainability 2017, 9, 600. [CrossRef]

55. Kusch-Brandt, S.; Brandt, K. Urban Renewable Energy on the Upswing: A Spotlight on Renewable Energy in Cities in REN21's “Renewables 2019 Global Status Report". Resources 2019, 8, 139. [CrossRef]

56. Abergel, T.; Dean, B.; Dulac, J. Towards a Zero-Emission, Efficient, and Resilient Buildings and Construction Sector. Available online: https://www.worldgbc.org/sites/default/files/UNEP\%20188_GABC_en\%20\% 28web\%29.pdf (accessed on 29 September 2020).

57. Bond, S. Barriers and drivers to green buildings in Australia and New Zealand. J. Prop. Invest. Finance 2011, 29, 494-509. [CrossRef]

58. Climate Bonds Initiative. Special Report Japan: Financing Low-Carbon Buildings and Energy Efficiency in the Green Bond Market. Available online: https://www.climatebonds.net/files/reports/cbi_gb_lcb_briefing_ 31012019.pdf (accessed on 30 September 2020).

59. EPA. United States environmental protection agency. Filtr. Sep. 1999, 36, 41. [CrossRef] 
60. Climate Action Plan. Available online: http://www.greenhoustontx.gov/climateactionplan/index.html (accessed on 30 September 2020).

61. UNIDO. Demand for Manufacturing: Driving Inclusive and Sustainable Industrial Development. 2018. Available online: https://www.unido.org/resources-publications-flagship-publications-industrialdevelopment-report-series/industrial-development-report-2018 (accessed on 30 September 2020).

(C) 2020 by the authors. Licensee MDPI, Basel, Switzerland. This article is an open access article distributed under the terms and conditions of the Creative Commons Attribution (CC BY) license (http://creativecommons.org/licenses/by/4.0/). 